\title{
Causality, Agency, and Control Beliefs in East Versus West Berlin Children: A Natural Experiment on the Role of Context
}

\author{
Gabriele Oettingen, Todd D. Little, Ulman Lindenberger, and Paul B. Baltes
}

\begin{abstract}
Beliefs about factors that affect school performance (means-ends or causality beliefs) and about selfefficacy and control (agency and control beliefs) were assessed in 313 East Berlin children (grades 26) before unification and in 516 West Berlin children shortly after unification. Multiple-group analyses of mean and covariance structures yielded 2 major differences: (a) East Berlin children showed lower agency and control beliefs than West Berlin children, and (b) their agency and control beliefs were more highly correlated with school grades than West Berlin children's, with strong correlations already emerging in East Berlin 2nd graders. Findings were consistent with differences between East and West Berlin school systems. East Berlin regulations (a) emphasized public performance feedback and public self-evaluation and (b) enforced unidimensional teaching strategies. Results point to a risk factor for development in East Berlin children.
\end{abstract}

In the formerly divided city of Berlin, we studied the role of contextual factors regarding the development of performancerelated causality, agency, and control beliefs and their connection to school performance. Beliefs about performance have important implications for performance itself and for subsequent ontogeny. This idea is the basis of an array of theories that deal with action and goal-oriented thinking, as reflected in judgments about expectancy and personal control (for a review see M. Baltes \& Baltes, 1986; Flammer, 1990; Sternberg \& Kolligian, 1990; Taylor, 1989). Researchers have focused, for instance, on the differentiation between various kinds of expectations (Bandura, 1986; H. Heckhausen, 1977; Weisz \& Stipek, 1982), on the development of judgments about expectancy and personal control, as well as on the relation of these beliefs to actual performance and subsequent development (Bandura, 1986, 1990; Chapman, Skinner, \& Baltes, 1990; Flammer, 1990; Frey \& Ruble, 1990; Harter, 1982; Helmke, 1992; Pekrun, 1987; Schunk, 1989, 1991; Seligman \& Elder, 1986; Skinner, Wellborn, \& Connell, 1990).

In the school domain, Skinner, Chapman, and Baltes (1988a, $1988 \mathrm{~b}, 1988 \mathrm{c}$ ) developed a model of performance-related beliefs based on action-theory considerations. Skinner et al. assumed that an action (i.e., goal-directed behavior) contains

We thank the children and teachers involved in the study for their cooperation and Markus von Bechtolsheim, Katrin Doll, Alexandra Freund, Jana Galinowski, Anita Günther, Kerstin Haenel, Ralph Krampe, Annette Losert, Anna Maciel, Doris Mayer, Ulrich Mayr, Verena v. Olberg, Petra Retzlaff, Beate Schroeder, Marianne Stall, Nicole Ueltzhoeffer, and Mirjam Wensauer for helping to collect the data. Special thanks go to Beate Doil for making initial contacts to the East Berlin schools. We gratefully acknowledge comments by August Flammer, Peter M. Gollwitzer, P. H. Hawley, Leo Montada, Peter M. Roeder, Gundel Schümer, Harry C. Triandis, Keith Widaman, and two anonymous reviewers on an earlier version of this article.

Correspondence concerning this article should be addressed to any of us at Max Planck Institute for Human Development and Education, Lentzeallee 94, 14195 Berlin, Germany. three basic entities: an actor, various means (e.g., effort), and an outcome (or end). Accordingly, three basic belief systems linking these entities are differentiated:

1. Means-ends beliefs or causality beliefs refer to the link between means (causes) and a given end (or outcome). These means-ends beliefs encompass children's beliefs about which causal factors or means (e.g., ability, luck, or powerful others), if present, lead to success (e.g., good school grades) or, if absent, to failure (e.g., bad school grades).

2. Agency beliefs refer to the link between actor and means and encompass children's beliefs about whether they personally have access to and can successfully apply school performancerelated means (e.g., access to effort or access to the help of the teacher).

3. Finally, Skinner et al. (1988a, 1988b, 1988c) defined a third type of belief, the control belief, which refers to the link between actor and end (or outcome) without specifying explicitly the means or causes. Control beliefs pertain directly to children's judgments of whether they are generally able to achieve school success (e.g., good school grades) and avoid school failure (e.g., bad school grades).

Other theories of expectancy and personal control also differentiate among these types of belief, but they do not compare them with each other within one integrated framework. For example, means-ends beliefs are similar to contingency beliefs (Nicholls \& Miller, 1985; Weisz, 1983; Weisz \& Stipek, 1982); here, the development of understanding contingencies is investigated (e.g., whether an event is caused by skill or chance) as well as the impact of such contingency beliefs on performance. Agency beliefs are similar to competence beliefs (Weisz \& Stipek, 1982) as well as self-efficacy beliefs, the latter of which are at the center of Bandura's (1986, 1990) social-cognitive learning theory. Self-efficacy beliefs describe the belief of a person as to whether he or she has the capabilities to perform certain actions in their relevant context. The definition of agency beliefs as put forward by Skinner et al. (1988a, 1988b, 1988c) not only considers capabilities pertaining to personal means such as effort and ability, but also refers to the child's presumed 
access to person-external means such as the teachers' help (i.e., powerful others). Control beliefs relate to the link between an actor and the desired goal (e.g., good school grades) and thus resemble the notion of expectations for success in the achievement motivation literature (Atkinson, 1957); here, extensive research has been focused on the influence expectations have on the choice of performance tasks and the evaluation of the respective outcomes. Researchers in this domain have also recognized that a differentiation between different types of expectations is useful for predicting readiness to achieve $(H$. Heckhausen, 1977).

Skinner et al. (1988a, 1988b, 1988c; see also Skinner et al., 1990) underlined the importance of the differentiation between the three kinds of belief systems using two different routes of research. First, they pursued structural measurement considerations (Skinner et al., 1988a, 1988b) and constructed a questionnaire, the Control, Agency, and Means-ends Interview (CAMI), which contains a separate subscale for each belief system. The items of the subscales are specifically tuned toward the theoretical differentiation between means-ends, agency, and control beliefs. Exploratory factor analyses of responses by children of various ages supported the hypothesized three-dimensional factor structure (Skinner et al., 1988a, 1988b; for more recent supporting validation using confirmatory multivariate techniques, see Little, Oettingen, Stetsenko, \& Baltes, 1993).

The second approach to showing the usefulness of differentiating between the three belief systems emphasized their differential relations or predictive validity to cognitive performance (e.g., Chapman et al., 1990). For example, pronounced correlational differences between the three belief systems have been observed in fourth and sixth grade children. Means-ends (causality) and control beliefs did not systematically relate to cognitive performance as measured by tests of fluid and crystallized intelligence (Horn, 1972; Wechsler, 1974). In contrast, a substantial relationship between agency beliefs and performance was demonstrated ( $r s=.40$ and .54 , respectively). ${ }^{1}$

For the development of school-performance-related meansends, agency, and control beliefs, two factors are of crucial importance: (a) children's age-dependent level of cognitive development (Rholes, Newman, \& Ruble, 1990; Ruble, 1983), which is critical because specific cognitive resources and skills are necessary to perform the relevant school-related cognitive operations, and (b) the school context, which is expected to modulate belief-performance contingencies (Ames, 1992; Ames \& Archer, 1988; Mac Iver, 1987, 1988; Rosenholtz \& Rosenholtz, 1981; Rosenholtz \& Simpson, 1984; Simpson, 1981; Stipek, 1984,1988 ). Because we were interested in the relative importance of age and context effects, we looked for children of different ages who were embedded in two different school contexts but stemmed from one culture. The contrast of East and West Berlin children provided such a quasi-experimental opportunity.

\section{Differences Between the East and West Berlin School Systems}

We conducted the present study in East Berlin 3 months before the political unification of the two Germanies and more than a year before the East German schools adopted the West
German school system. For centuries, people in East and West Berlin shared a common cultural heritage and lived under the same political systems; however, between 1945 and 1990, they were governed by two different political systems (communism vs. social capitalism). For this reason, possible differences in East and West Berlin children's performance-related beliefs most likely stem from the political system differences and their consequences (e.g., economical, educational, and social-structural; see Oettingen, in press; Oettingen \& Seligman, 1990). More specifically, the different political systems in East and West Berlin produced two different school systems with different goals, regulations, and a different everyday school life ("DDR: Schule im Aufbruch," 1990; Giessmann, 1990; Klier, 1990; Waterkamp, 1990). Three major differences were (a) the age of onset of the grading procedures, (b) the way in which performance feedback was given, and (c) the degree of unidimensionality in teaching strategies.

In East Berlin, differentiated performance feedback in the form of grades was given right from the beginning of school (i.e., first grade) and in front of the whole class (which was called class collective). Furthermore, other teacher evaluations, expressed both verbally and nonverbally, were to be given throughout the school day (Franz, 1987; Schnabel, 1977; Tautz, 1978; Weck, 1981; Witzlack, 1986). Finally, teachers were expected to publicly evaluate their students outside the class context, such as at parent-teacher assemblies, at the parents' workplaces, or at meetings of the state-organized youth organizations (i.e., Pioneers and Free German Youth; Franz, 1987; Waterkamp, 1990). In addition to this kind of performance feedback, teaching strategies in East Berlin were more group-focused and unidimensional (Rosenholtz \& Rosenholtz, 1981; Rosenholtz \& Simpson, 1984) than in West Berlin, thereby enhancing social comparison and evaluation practices. Across all schools in the former East Germany, children of a given grade level received exactly the same materials, tasks, and pace of studying, irrespective of the children's interests or potential. Moreover, teachers were required to strictly adhere to the curriculum, regulations, and pace of studying and were not to give in to the specific needs of the individual student (Waterkamp, 1988, 1990).

To support the East Berlin teaching strategies and the way of giving feedback to students, teacher training in the former East Germany stressed "adequate" and differential self-evaluation

\footnotetext{
'This finding is not consistent with Skinner, Wellborn, and Connell (1990), who, instead of referring to means-ends and agency beliefs, talked about strategy and capacity beliefs, respectively. Although agency and capacity beliefs are operationalized in similar ways, strategy and means-ends beliefs are not. Strategy beliefs as operationalized by Skinner et al. (1990) reflect children's judgments on what factors cause school success and avoid school failure for the children themselves. In contrast, means-ends beliefs as operationalized by the CAMI (see Little, Oettingen, Stetsenko, \& Baltes, 1993; Skinner, Chapman, \& Baltes, $1988 \mathrm{a}, 1988 \mathrm{~b}$, and the present study) reflect children's judgments on what factors cause good and bad school performance in children in general. This conceptual difference explains why Skinner et al. (1990) found significant correlations between strategy beliefs and measures of both academic and cognitive performance, whereas consistent with our findings, Chapman, Skinner, and Baltes (1990), using the CAMI, found largely nonsignificant relations between means-ends beliefs and performance.
} 
as the developmental core of an independent and responsible personality (Falkenhagen, 1989; Finck, 1989; Franz, 1982, 1987, 1989; Krause, 1989; Wiese, 1989). Teaching children to conform with the teachers' opinion was part of the larger political program, guided by the official party of the former East Germany, that aimed at educating (and reeducating) "harmoniously developed socialistic personalities" (Waterkamp, 1990, p. 263). Accordingly, one central goal of the educational philosophy in East Berlin was to foster, in all students, the ability to evaluate themselves adequately, that is, according to the judgment of the teacher (Franz, 1982, 1987, 1989). For example, Franz $(1982,1987,1989)$ took great care in stressing that teaching adequate self-evaluation should be the goal not only of the teacher, but also of the parents and the class-collective and, furthermore, that an "open and honest" climate in the class-collective, which is based on the confrontation of self- and peer evaluation, is necessary for good performance and successful development on the part of the student and the collective as a whole (see also Waterkamp, 1990). Finally, characteristics such as quietness and modesty were desirable in East Berlin children, whereas feelings of "knowing better" and "superiority" were undesirable in children's personality development (Franz, 1987; Weck, 1981).

We know of no empirical data with respect to the implementation of the goals set by the former East Germany in everyday school life of East Berlin schools. However, P. M. Roeder (personal communication, September 16,1990 ) reported on learning conferences, where, after having to publicly evaluate themselves, "good" students were praised, whereas "bad" students were asked to self-critically explain why they had not performed better and how they planned to improve their school performance (see also Franz, 1982, 1987; Schnabel, 1977; Tautz, 1978; Weck, 1981). These unshrouded self-revealings could then be commented on and criticized by both teachers and peers. Furthermore, every student was supposed to feel responsible for the successes and failures of the class-collective. Finally, the schools were in contact with the "work collectives" of the students' parents, which themselves were held responsible for successes and failures of their members' children (P. M. Roeder, personal communication, September 16, 1990).

In West Berlin, the school system's regulations and educational goals were different (Waterkamp, 1990). Performance feedback in the form of grades was not given until the very end of the second grade and more privacy was targeted, although it could not be guaranteed. No public self-evaluations were demanded, and children's performance records were kept in the schools, not to be discussed in public forums such as parentteacher assemblies. Teaching strategies were less unidimensional (i.e., task, materials, and pacing were more varied), and teachers were allowed to accommodate to the individual needs of the children to a greater extent than in East Berlin. These differences in regulations and teaching strategies between East and West Berlin school systems were also reflected in different educational goals: In West Berlin, there was no explicit educational goal toward realistic or "adequate self-evaluation." Rather, the educational philosophy was focused on transmitting factual knowledge to the children and on refraining from directing children's personalities into a "realistic orientation" or any other state-defined value system (Waterkamp, 1987, 1990).
Expected Similarities and Differences Between East and West Berlin Children's School Performance-Related Beliefs

\section{Mean Level}

Concerning means-ends or causality beliefs, we expected much commonality. Specifically, East and West Berlin children should not differ in their beliefs about the extent to which the a priori defined causes (i.e., effort, ability, luck, teachers, and unknown) influence performance, because these dimensions assess rather global sociocultural beliefs about how school success is attained and failure is avoided.

With respect to the level of personal agency and control beliefs, however, we expected lower levels in East Berlin than in West Berlin because the goals of the East Berlin school system were to teach their students an "adequate self-evaluation" (Franz, 1982, 1987; see also Helwig, 1988; Krause, 1989; Waterkamp, 1990; Weck, 1981). In contrast to West Berlin children who were embedded in a school context emphasizing confidential performance feedback, East Berlin children were exposed to public performance evaluations by their teachers and the class-collective, leading to a socially shared and unambiguous performance history. Accordingly, we hypothesized that East Berlin children, having fewer opportunities to use self-protective strategies such as self-enhancement (see Franz, 1987), would show lower (more pessimistic) levels of performance-related self-efficacy and control beliefs than West Berlin children.

\section{Correlation With School Performance}

On the basis of past research (Chapman et al., 1990), we expected stronger correlations with performance for agency beliefs than for control beliefs as well as small or nonsignificant correlations for means-ends beliefs in both East and West Berlin. Differences between East and West Berlin children should emerge, however, in the strength of the positive correlation between performance and personal agency/control beliefs, because the East and West Berlin school contexts differed in various critical contextual influences. For example, differentiated and unambiguous feedback on children's performance increases the strength of relationship (i.e., accuracy) between estimates of subjective potential and actual performance (Franz, 1982; Rosenholtz \& Rosenholtz, 1981; Rosenholtz \& Simpson, 1984; Simpson, 1981). This effect should be particularly strong when the feedback is given publicly in the classroom because public feedback allows for a comparison between peers and for a precise estimate of one's rank in class (Franz, 1982; see Stipek, 1984, 1988). Also, in the East Berlin schooling context, the fact that a child's class rank was discussed in front of the whole class created a social reality that could not be easily changed.

East Berlin's educational focus on "realistic performance feedback" and on "socially shared feedback," therefore, made us expect a stronger connection between agency/control beliefs and academic performance in East Berlin than in West Berlin children. Finally, we expected a comparatively earlier onset of the connection between agency/control beliefs and school performance in East Berlin because public performance feedback was initiated already in the first grade. 
Method

\section{Subjects}

Across the two studies, a total of 830 male $(n=400)$ and female $(n=$ 430) children participated. Specifically, 176 boys and 137 girls were tested in East Berlin and 224 boys and 293 girls in West Berlin. All children came from a middle to lower middle socioeconomic background. The average age of the second graders was 8.6 years, of the third graders 9.6 years, fourth graders 10.6 years, fifth graders 11.7 years, and sixth graders 12.6 years; the two samples from East and West Berlin did not differ in age.

We conducted the East Berlin part of the study in the beginning of July 1990; the West Berlin data were collected in June 1991. The.year's delay was due to organizational difficulties. Because the political context was changing more rapidly in East than in West Berlin, we chose to test the East Berlin children first. In each grade level, 54 to 74 children were tested from two East Berlin schools and 73 to 115 children were tested from two West Berlin schools. All tests (multivariate analysis of variance [MANOVA] and univariate analysis of variance [ANOVA]) of possible differences between the two schools within East and West Berlin on the target variables of this study were nonsignificant.

\section{Instruments}

CAMI. On the basis of analyses of the psychometric characteristics of the original CAMI instrument (i.e., Skinner et al., 1988a, 1988b), a shortened and psychometrically improved version, containing 58 of the 80 original items, was used in the current analyses (Little et al., 1993). The CAMI instrument assesses three categories of school-performancerelated beliefs:

1. Means-ends beliefs refer to children's judgments of the extent to which five a priori defined means or causal factors influence school performance. The causal factors are effort, ability, luck, teachers, and unknown (the last category yields high values when children say that they do not know what causes good and bad school grades). The CAMI questionnaire used in this study contains six items for each of the different means; three items pertain to the effects of the presence of the specified mean and three items pertain to the absence of it.

2. Agency beliefs consist of children's judgments as to the extent they personally have access to four a priori defined performance-related means, namely, effort, ability, luck, and help of teachers. For each mean, there are three positively and three negatively worded items.

3. Control beliefs focus on the children's beliefs as to whether they can control their own school performance without specifying the means or causes; this dimension is measured by four positively worded items.

Table 1 shows item examples. The children answered all items on a 4-point scale ranging from never to always. Technical reports are available that describe the scale construction in detail (Little et al., 1993; Skinner et al., 1988a).

Factor structure of the CAMI. The psychometric properties and the factorial structure of the CAMI as described in earlier publications (Skinner et al., 1988a, 1988b, 1988c) correspond to more recent confirmatory analyses (Little et al., 1993). Specifically, means-ends beliefs emerged as 5 factors representing the four performance-related means of effort, ability, luck, teachers, and a 5th factor representing unknown causes. Agency beliefs emerged as $\mathbf{4}$ factors representing the categories of effort, ability, luck, and teachers. Finally, control beliefs marked the 10 th factor. In addition, second-order analyses of the four agency belief dimensions suggested a 2-factor structure: (a) a second-order dimension that encompassed beliefs about effort, ability, and luck (termed Agency: $E A L)$ and (b) a first-order dimension representing the teacher dimension (termed Agency: Teacher). (See Little et al., 1993, for details of this type of representation.)

In the Little et al. (1993) analyses, the concordance of the CAMI fac- tor structure was tested for seven populations (East Berlin, West Berlin, Los Angeles, Moscow, Prague, Warsaw, and Tokyo) using a multiplegroup mean and covariance structures (MACS) framework (Bentler, 1989; Jöreskog \& Sörbom, 1989; Little, 1993; and see the Appendix for details of the model). The results supported strongly the equivalence of the factor structure across the seven populations (including the East and West Berlin samples used in the present study). In addition, the factor reliabilities were all acceptable, ranging from .59 to .89 with a median of .75. From these more recent results and data published earlier (Skinner et al., 1988a, 1988b, 1988c), we can conclude that the CAMI is a measurement instrument with good psychometric properties and structural equivalence across samples from diverse cultural backgrounds.

\section{Assessment Procedures}

We gave the CAMI to the children in their classrooms during school time, reading each item aloud while the children silently followed along. We told the children that neither their teachers, their parents, their classmates, nor anyone else they knew would see their answers. Furthermore, we explained that there were no right or wrong answers and that everyone should just write down which answer they themselves thought would fit best.

We took the year-end grades for mathematics and language from the class records. The grade for language was the average for oral expression, written expression, and orthography; mathematics was measured as a single grade.

\section{Analytic Procedures}

Multiple-group mean and covariance structures (MACS) analyses as statistical strategy. The MACS analysis framework (see Bentler, 1989; Jöreskog \& Sörbom, 1989; Little, 1993), which we used throughout, has two main advantages: It explicitly tests for equivalence of comparison (i.e., metric invariance) and it corrects for measurement error (i.e., disattenuation).

First, a MACS framework can test whether comparisons between groups are made on the same underlying construct (Baltes \& Nesselroade, 1973). This test is accomplished by specifying equality of the measurement level across groups (i.e., metric invariance of the measurement model) and evaluating the goodness of fit. Thus, our first analytic goal was to establish the equivalence of both the factor loadings as well as the mean levels for each indicator across all groups. If this condition is supported by the data, then by definition, all between-groups comparisons at the latent level are made on equivalently defined constructs.

A second advantage of MACS analyses is that information in the factor space is represented at a reliable, disattenuated level. This disattenuation not only applies to the covariances and variances but also to the means of the latent factors. As a consequence, any comparison of the covariations as well as the means of the latent constructs is made at a disattenuated (i.e., more veridical) level of analysis.

Model structure. We first performed MACS analyses on the overall East $(n=313)$ and West Berlin $(n=517)$ samples (i.e., a two-group MACS model). Then, in a second set of analyses, we compared each grade level within East and West Berlin (i.e., a 10-group MACS model, five grade levels each for East and West Berlin).

Our analyses followed a two-step process. First, we estimated and tested the measurement model for its adequacy; here, we specified metric invariance of the measurement space but placed no constraints on the latent space. That is, we constrained the factor loadings and mean estimates of each indicator for a given latent factor to be equal for each group in the analysis (e.g., East Berlin vs. West Berlin in the two-group analyses). However, we allowed the mean, variance, and covariances for a given latent factor to vary freely both within and between each group. Second, assuming we obtained an acceptable level of fit for this model, 
Table 1

Item Examples for Different Categories of Performance-Related Beliefs

\begin{tabular}{|c|c|c|}
\hline Means & Positive events & Negative events \\
\hline & \multicolumn{2}{|c|}{ Means-ends beliefs } \\
\hline Effort & $\begin{array}{l}\text { When a child knows a lot about } \\
\text { something, is it because the child } \\
\text { works hard at learning it? }\end{array}$ & $\begin{array}{l}\text { When children do not learn very much } \\
\text { in class, is it because they do not } \\
\text { work very hard? }\end{array}$ \\
\hline Ability & $\begin{array}{l}\text { A child manages to learn hard } \\
\text { things in school. Is it because the } \\
\text { child is smart? }\end{array}$ & $\begin{array}{l}\text { A child gives the wrong answer to a } \\
\text { teacher's question. Is it because the } \\
\text { child simply is not smart enough? }\end{array}$ \\
\hline Luck & $\begin{array}{l}\text { Is doing well at school a matter of } \\
\text { luck? }\end{array}$ & $\begin{array}{l}\text { When children get bad grades, is it } \\
\text { because they have bad luck? }\end{array}$ \\
\hline Teacher & $\begin{array}{l}\text { Let us say that a child gets good } \\
\text { grades. Is that because the child } \\
\text { gets along well with the teacher? }\end{array}$ & $\begin{array}{l}\text { Let us say that a child gets bad grades. } \\
\text { Is it because the teacher does not } \\
\text { like that child? }\end{array}$ \\
\hline \multirow[t]{2}{*}{ Unknown } & $\begin{array}{l}\text { When children get good grades in } \\
\text { school, is it hard to know why? }\end{array}$ & $\begin{array}{l}\text { When children mess up in school, is it } \\
\text { hard to figure out why that happens? }\end{array}$ \\
\hline & \multicolumn{2}{|c|}{ Agency beliefs } \\
\hline Effort & I can really pay attention in class. & $\begin{array}{l}\text { I have trouble paying attention in } \\
\text { class. }\end{array}$ \\
\hline Ability & $\begin{array}{l}\text { I am pretty smart in school-even } \\
\text { without working very hard. }\end{array}$ & I am just sort of dumb in school. \\
\hline Luck & $\begin{array}{l}\text { When it comes to getting good } \\
\text { grades, I usually have lots of luck. }\end{array}$ & $\begin{array}{l}\text { As far as learning something hard goes, } \\
\text { I am usually out of luck. }\end{array}$ \\
\hline Teacher & $\begin{array}{l}\text { I have teachers who will help me } \\
\text { when I want them to. }\end{array}$ & $\begin{array}{l}\text { I have a hard time getting the teacher } \\
\text { to help me even when I need help. }\end{array}$ \\
\hline
\end{tabular}

Control beliefs

If I want to do well in school, I can.

we evaluated the latent parameter estimates and their associated standard errors.

For the 2-group MACS comparisons, we included three additional variables in the models to estimate and thus control for (i.e., partial) their effects: the first was a dummy-coded variable representing the effects of gender (gender), the second represented the linear effects of grade in school (grade), and the third represented the quadratic effects of grade in school (grade ${ }^{2}$; obtained by squaring grade level). For the 10-group (i.e., by grade) MACS analyses, we added only the dummy-coded variable representing gender. We also estimated an Academic Performance factor in each model using the grades for mathematics and language as two separate indicators. Mean differences in the mathematics and language grades were removed by standardizing (i.e., a $z$ transformation) within the level of the classroom (see the Appendix for more details).

In each of the measurement models, we estimated the effects of the additional variables as a directed path to each factor, except for the Academic Performance factor; here, we estimated the effects of gender directly at the level of the indicators because differential patterns of gender effects may exist for mathematics and language performance.

For both the 2-group and the 10-group MACS analyses, we fit two forms of model. In the first model, we estimated the effects of Agency: EAL, and in the second model, we estimated these effects separately for each category (Agency: Effort, Agency: Ability, Agency: Luck-which were represented using the three respective indicators of each factor). This dual analysis approach allowed us to evaluate whether the separate categories behave differently for any of the groups or for any of the grade levels (see the Appendix for more details).

\section{Results}

\section{Overall Group Comparisons}

We fit the two models described above (i.e., with Agency: EAL combined and separated) to the data, and both provided very good levels of fit (see the Appendix). We estimated both of these models such that no additional estimates beyond the a priori specifications described above were necessary.

Mean differences. Figure 1 presents the estimated mean differences between the East and West Berlin sample for the agency dimensions, Agency: EAL and Agency: Teacher, and the control belief dimension, Control. The results are in agreement with our predictions. ${ }^{2}$

East Berlin children showed lower levels of agency and control beliefs than West Berlin children. The specific values were, for Agency: EAL, $z=4.16, p<.001$; for Agency: Teacher, $z=3.34$, $p<.001$; and for Control, $z=3.09, p=.001$. These differences accounted for $3.1 \%, 2.8 \%$, and $2.0 \%$ of the variance in each of the respective dimensions. The mean differences for the three agency dimensions (i.e., effort, ability, and luck) estimated separately all followed a pattern similar to that of Agency: EAL. For each dimension, East Berlin children showed lower values than the West Berlin children; specifically, for Agency: Effort, $M=2.88$ versus $3.29, z=4.85, p<.001$; for Agency: Ability, $M=2.71$ versus 2.95, $z=2.80, p=.003$; and for Agency: Luck, $M=2.58$ versus $2.88, z=3.46, p<.001$.

Regarding causality or means-ends beliefs, only one of the five dimensions showed a difference-for Means-ends: Teacher, $z=-3.60, p<.001$, accounting for $2.3 \%$ of the variance. As can be seen in Figure 2, the East Berlin children had a comparatively higher score. In other words, as compared with the West

\footnotetext{
${ }^{2}$ All results of the analyses at the raw data level were substantively similar to the MACS results reported throughout this article.
} 


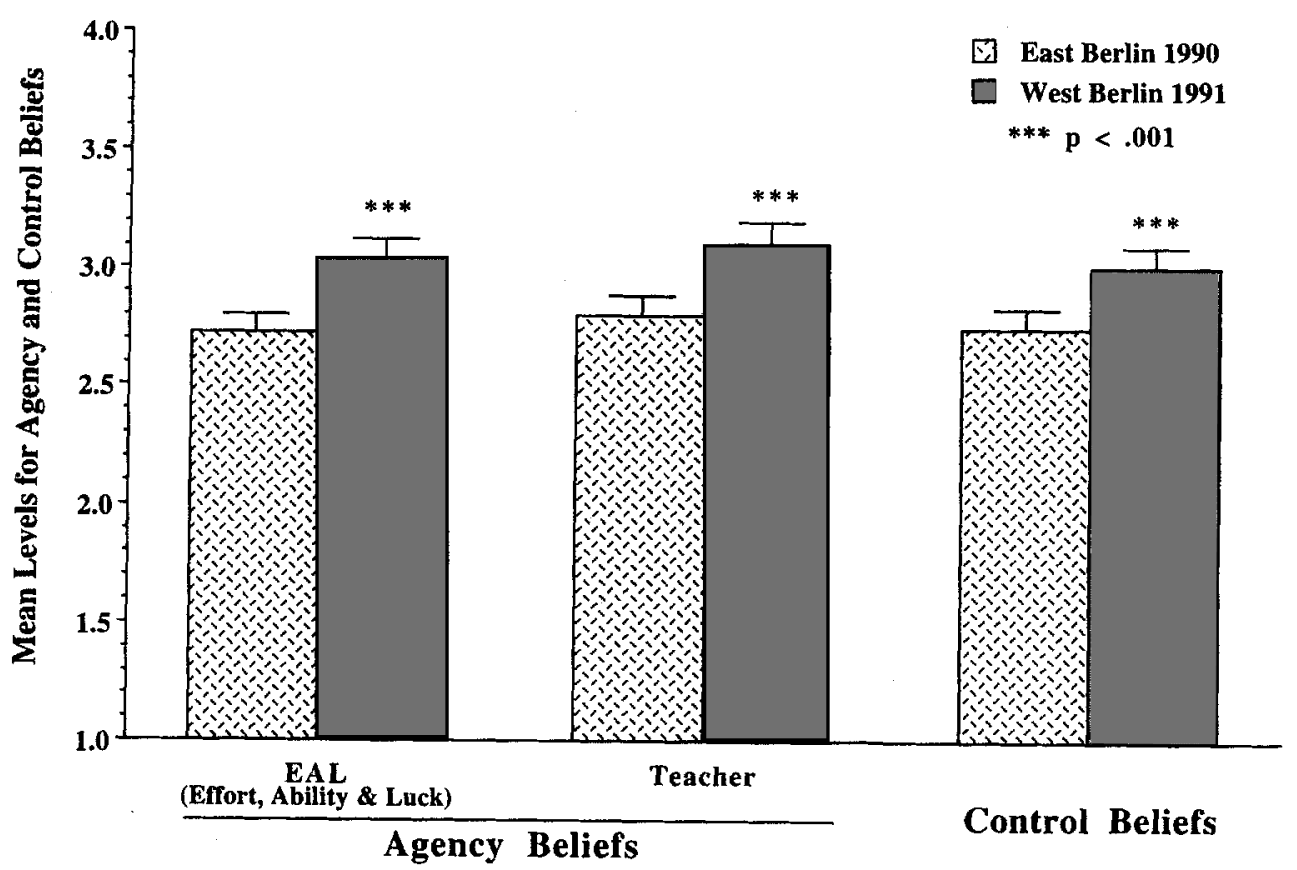

Figure 1. Latent (LISREL) estimates of mean differences between East $(n=313)$ and West $(n=517)$ Berlin children for three of the Control, Agency, and Means-ends Interview constructs: Agency: EAL, Agency: Teacher, and Control. (Error bars indicate $1 / 2$ of the $95 \%$ confidence interval, one-tailed.)

Berlin children, East Berlin children assigned the help of the teachers a more important role in producing school performance. East and West Berlin children did not differ in the remaining four means-ends beliefs: for Means-ends: Effort, $z=$ 1.33, $p=.18$; for Means-ends: Ability, $z=0.30, p=.77$; for Means-ends: Luck, $z=-0.78, p=.43$; and for Means-ends: Unknown, $z=-2.11, p=.043$.

Strength of relationship to academic performance. Figures 3 and 4 present the estimated strengths of the relationship between school performance and the CAMI factors. As we had predicted, the link between Academic Performance and the two primary categories of agency beliefs (i.e., Agency: EAL and Agency: Teacher) as well as control beliefs was stronger among East Berlin than among West Berlin children $(z=5.85, p<$ $.001 ; z=2.32, p=.01 ;$ and $z=3.00, p=.001$, respectively; see Figure 3). Furthermore, the Agency: EAL factor, when estimated as three separate dimensions, produced the same pattern of differences, with East Berlin children showing uniformly stronger relations than West Berlin children: specifically, for Agency: Effort, $r=.72$ versus $.63, z=4.68, p<.001$; for Agency: Ability, $r=.74$ versus $.69 z=2.46, p<.01$; and for Agency: Luck, $r=.74$ versus $.62, z=5.51, p<.001$. In other words, the predictive validity of the agency and control factors with school performance was higher in East Berlin than in West Berlin children. In terms of effect size, the agency dimensions (i.e., Agency: EAL) captured 59\% of the reliable school performance variance in East Berlin and only $46 \%$ in West Berlin.

In contrast, and as we had predicted, the link between causality or means-ends beliefs and Academic Performance was much lower than the agency and control belief dimensions. Specifically, with the exceptions of Means-ends: Effort and Meansends: Ability, these correlations were not different from zero.
Finally, no differences between east and West Berlin children appeared; specifically, for Means-ends: Effort, $z=1.37, p=.17$; for Means-ends: Ability, $z=1.09, p=.27$; for Means-ends: Luck, $z=-1.32, p=.19$; for Means-ends: Teacher, $z=0.13$, $p=.90$; and last, for Means-ends: Unknown, $z=-0.75, p=.46$ (see Figure 4). That the correlations with school performance were lower for means-ends beliefs than for agency and control beliefs replicates earlier research by Chapman et al. (1990) with West Berlin children. ${ }^{3}$

The predictive power of agency beliefs and control beliefs. We also analyzed the relative predictive power of the two kinds of belief that demonstrated significant relationships with school grades (i.e., agency and control). Specifically, we tested whether control beliefs shared any unique variance with school achievement after controlling for agency beliefs (i.e., Agency: EAL), and vice versa.

First, we specified a two-group MACS model with Control beliefs predicting Agency: EAL and Agency: EAL predicting Academic Performance. Allowing for a direct path from Control beliefs to Academic Performance did not lead to significant increments in fit (East Berlin, $z=1.92, p>.05$; West Berlin, $z=1.67, p>.05$; the paths in both groups were negative). In other words, the predictive variance of Control beliefs to Academic Performance could be represented as being fully mediated through agency beliefs (i.e., Agency: EAL). In the reverse model, Agency: EAL predicted Control beliefs, and Control beliefs predicted Academic Performance. In this case, allowing for

\footnotetext{
${ }^{3}$ It seems justified to use a conception of agency, control, and meansends not specifying mathematics and verbal performance separately, because in East as well as in West Berlin mathematics and verbal grades were highly related $(r s>.72$ ) and reliable (Cronbach's $\alpha>.84$ ).
} 


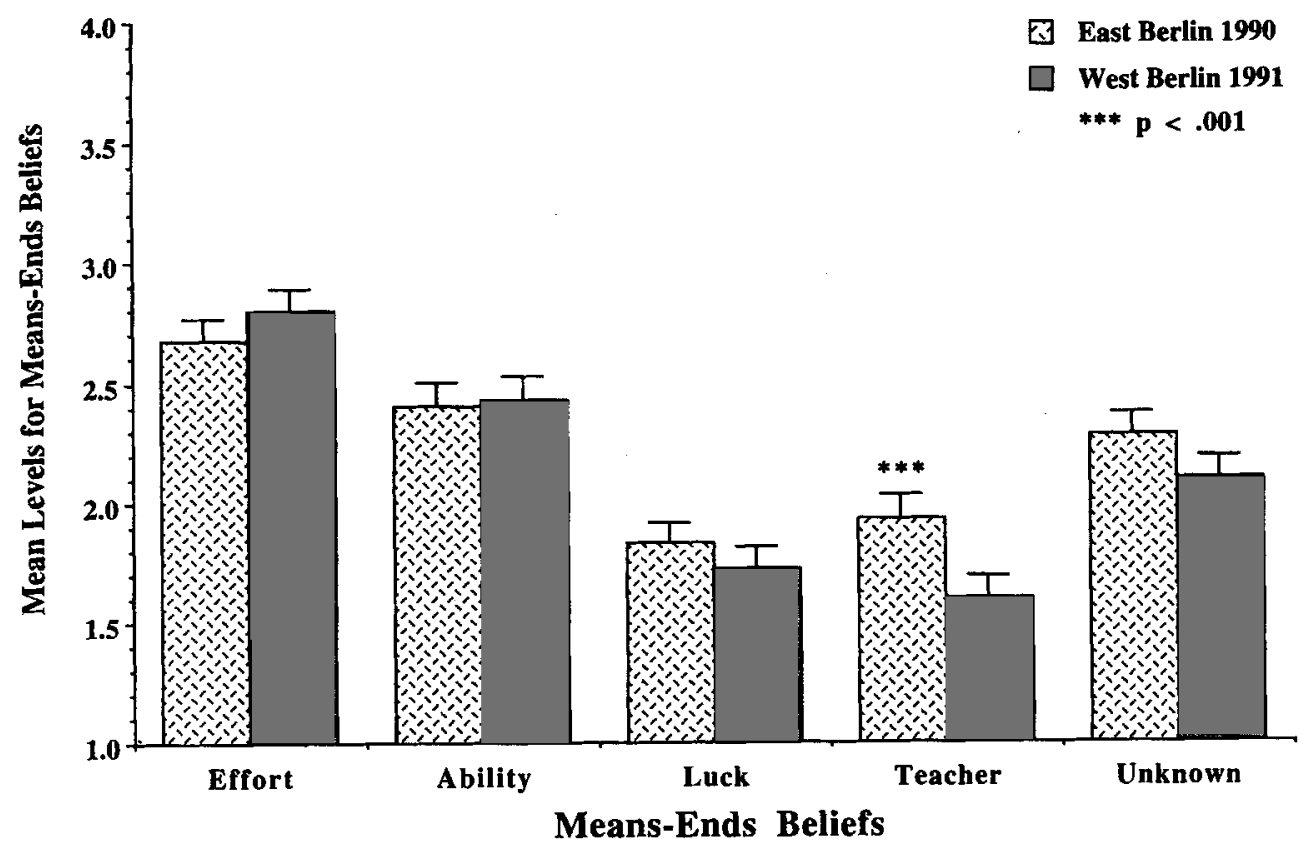

Figure 2. Latent (LISREL) estimates of mean differences between East $(n=313)$ and West $(n=517)$ Berlin children for the five Means-ends constructs: (Error bars indicate $1 / 2$ of the $99 \%$ confidence interval, two-tailed.)

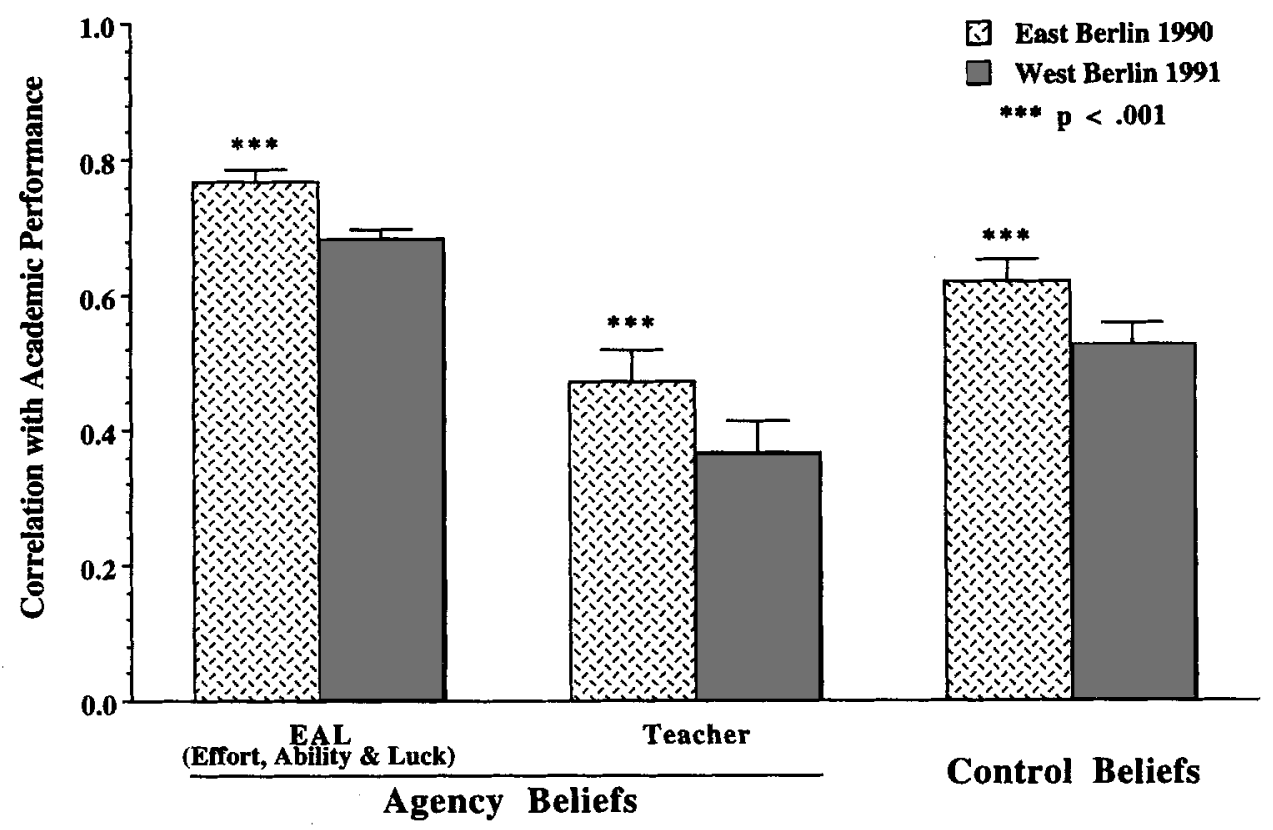

Figure 3. Latent (LISREL) estimates of the differential strengths of relationship between Academic Performance and three of the CAMI constructs (Agency: EAL, Agency: Teacher, and Control) for East ( $n=$ 313 ) and West $(n=517)$ Berlin children. (Error bars indicate $1 / 2$ of the $95 \%$ confidence intervals of the estimated standardized covariances, one-tailed. Hierarchical regressions showed that Control beliefs do not provide any unique prediction of Academic Performance when Agency: EAL was entered.) 


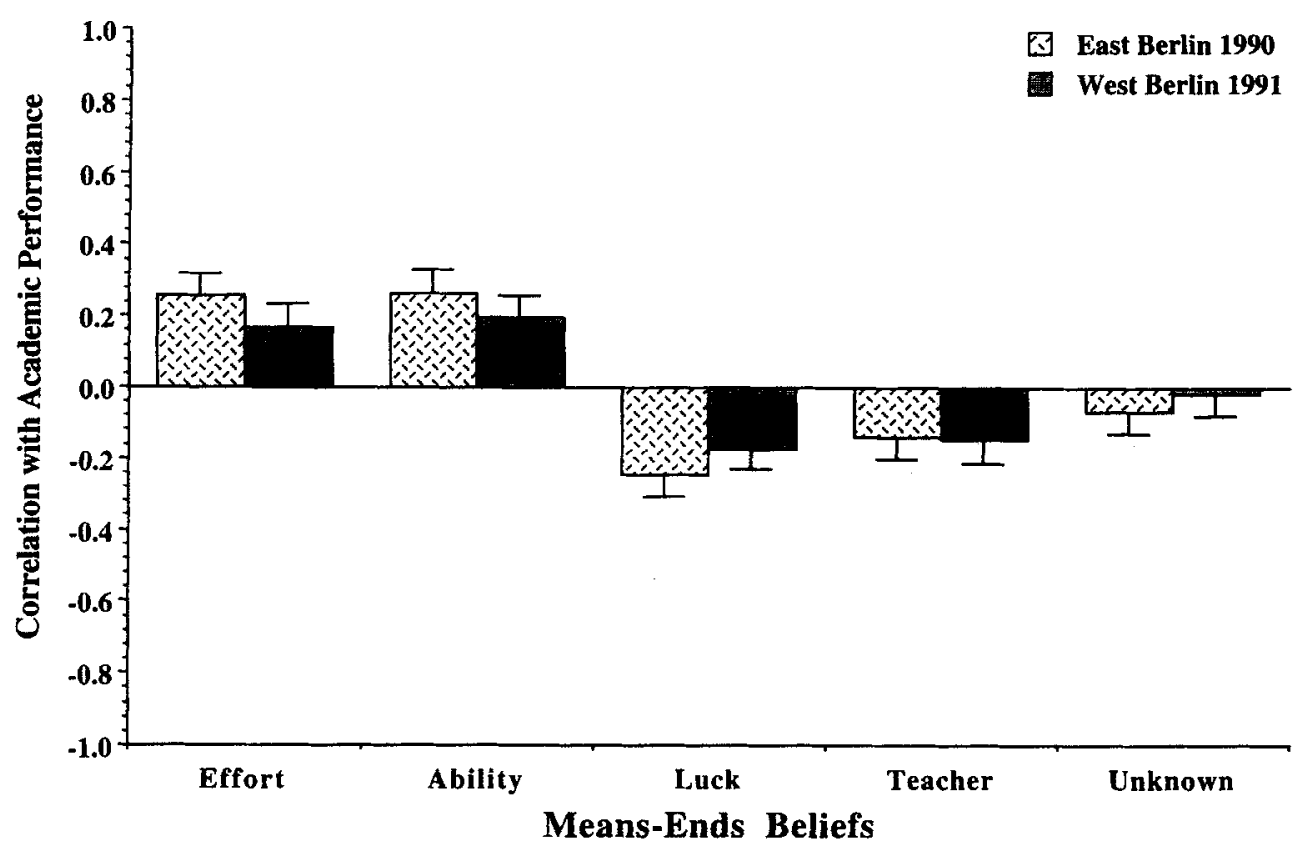

Figure 4. Latent (LISREL) estimates of the differential strengths of relationship between academic. performance and the five Means-ends dimensions for East $(n=313)$ and West $(n=517)$ Berlin children. (Error bars indicate $1 / 2$ of the $99 \%$ confidence intervals of the estimated standardized covariances, two-tailed.)

a direct path from Agency: EAL to Academic Performance led to significant improvements in fit (East Berlin, $z=3.39, p<$ .001 ; West Berlin, $z=5.13, p<.001$ ), with Agency: EAL having a positive effect on Academic Performance.

Thus, adding control beliefs as a predictor of school achievement after controlling for agency beliefs did not lead to a significant increment in explained variance. However, adding agency beliefs after controlling for control beliefs did. These results are in agreement with past research (Chapman et al., 1990) and our expectation to find the strongest relationship to achievement in agency beliefs because they refer to children's subjective potential to use specific outcome-relevant means.

\section{Comparisons by Grade (Age): Agency and Control Beliefs}

We now want to decompose the findings by grade level and gender (see the Appendix for details). Because the pattern of findings for the three agency dimensions of effort, ability, and luck, when estimated as separate factors, provided the same pattern of results as the combined, Agency: EAL factor, only the combined Agency: EAL results are presented.

Mean differences. The mean differences, by grade level, for agency and control beliefs are presented in Figure 5. On a descriptive level, 8 of the 15 possible comparisons showed significant differences and 2 showed marginal trends. All of these were in the hypothesized direction, with East Berlin children showing lower scores than West Berlin children.

As is seen in the top panel of Figure 5, for Agency beliefs: EAL, East Berlin children evinced lower mean levels than West Berlin children at each grade level, except Grade 2 (Grade 2, $z$
$=0.22, p=.41 ;$ Grade $3, z=2.77, p=.003 ;$ Grade $4, z=1.46$, $p=.07$; Grade 5, $z=1.82, p=.03$; and Grade $6, z=2.80, p=$ .003 ; see Figure 5, top panel). Similarly, lower mean levels were found for Agency: Teacher in Grades 3, 4, and $5(z=2.19, p=$ $.01 ; z=1.92, p=.03$; and $z=2.48, p=.007$, respectively; see Figure 5, middle panel), although no differences were found in Grades $2(z=0.01, p=.49)$ and $6(z=-0.17, p=.43)$. Finally, East Berlin children showed lower levels of control beliefs than West Berlin children in Grades 3, 5, and $6(z=2.19, p=.01 ; z$ $=1.45, p=.07$; and $z=2.08, p=.02$, respectively. No differences were found in Grades $2(z=0.13, p=.45)$ and $4(z=$ $0.89, p=.19$; see Figure 5, bottom panel).

Gender differences and age trends. A gender difference emerged only for Agency: Teacher $(z=3.31, p<.01)$, with girls scoring higher than boys $(\beta=.14)$. In other words, girls believed they had more access to teachers than boys. Regarding the age trends, Agency: EAL showed only a slightly decreasing linear component that was the same for East and West Berlin children ( $z=-2.28, p<.05$; see Figure 5, top panel). Agency: Teacher (Figure 5, middle panel) did not show any developmental trends; that is, the means were flat and parallel across grade levels (for the linear trend, $z=-0.86, p>.05$, and for the quadratic trend, $z=0.02, p>.05$ ). Finally, Control beliefs showed a slight $U$-shaped quadratic trend that was the same for both the East and West Berlin samples $(z=2.27, p<.05$; see Figure 5, bottom panel).

Strength of relationship to Academic Performance. The estimated, disattenuated relationships between the CAMI constructs and the Academic Performance factor for each grade level are presented in Table 2 (labeled $D i s$ ). As a point of com- 


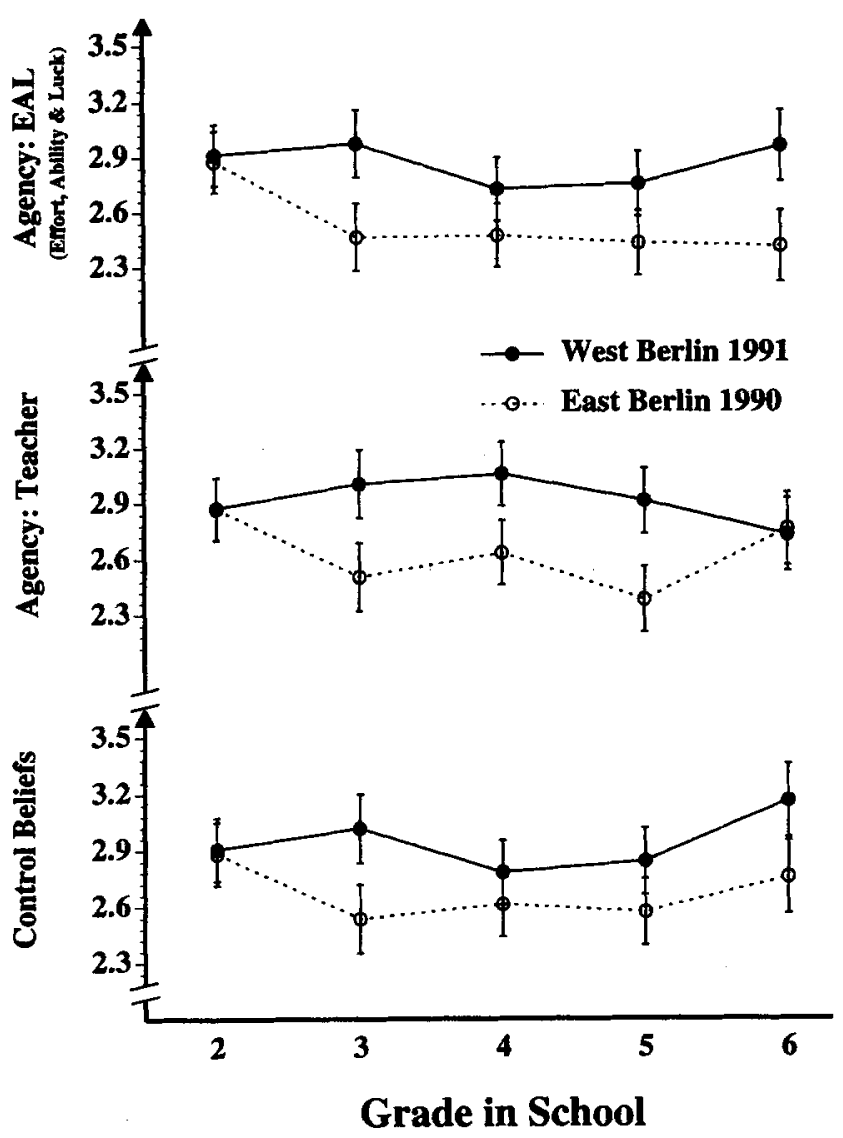

Figure 5. Latent (LISREL) estimates of mean differences between East and West Berlin children for Agency: EAL (top panel), Agency: Teacher (middle panel), and Control (bottom panel), presented by grade level. (Error bars indicate 1/2 of the $95 \%$ confidence intervals of the estimated means, one-tailed.)

parison, the raw data correlations (labeled Raw) are also presented; note that although all observed relations are lower for the raw data correlations than the disattenuated correlations, the pattern of East versus West Berlin differences is similar.

For Agency: EAL, stronger relationships were found among East Berlin than among West Berlin children at all grade levels, except Grade 4, where there was a difference in the opposite direction (Grade 2, $z=4.72, p<.001$; Grade 3, $z=3.37, p<$ .001 ; Grade $4, z=-1.59, p=.112$; Grade $5, z=2.30, p<.01$; and Grade 6, $z=3.70, p<.001$ ). For Agency: Teacher, a stronger relationship was found in the East Berlin sample for Grade $6(z=3.63, p<.001)$ and Grade $3(z=1.77, p<.05)$, a marginal difference was found for Grade 2 ( $z=1.47, p=.07$ ), and no significant relationship was found for the remaining grades (Grade 4, $z=-0.35, p=.36$, and Grade 5, $z=0.52, p=$ .30).

Finally, Control beliefs evinced comparatively stronger relationships for East Berlin than for West Berlin children in Grades 2,3 , and $6(z=2.40, p=.008 ; z=2.84, p=.002 ;$ and $z=3.02$, $p=.001$, respectively), whereas no differences were found for Grade $4(z=-0.28, p=.39)$ and Grade $5(z=0.29, p=.39)$.

\section{Comparisons by Grade (Age): Means-Ends Beliefs}

Mean differences. Hardly any differences emerged between East and West Berlin children in means-ends or causality beliefs. Of 25 possible differences between East and West Berlin children, only 2 were significant. These differences, however, appear systematically related to age and grade. Specifically, Means-ends: Teacher showed differences in Grades 5 and $6(z=$ $-3.28, p=.001$ and $z=-2.68, p=.004$, respectively). For each of these differences, East Berlin children scored higher than West Berlin children (for Grade 5, $M=2.05$ and $M=1.20$, respectively, and for Grade $6, M=2.35$ and $M=1.65$, respectively); that is, older East Berlin children assigned more importance to the teachers' role in regulating school performance than did their West Berlin peers. Means-ends: Effort, Meansends: Ability, Means-ends: Luck, and Means-ends: Unknown showed no differences (only a single difference favoring East Berlin children appeared for Means-ends: Unknown in Grade 3, $M=2.70$ for East Berlin and $M=2.49$ for West Berlin, $z=$ $-2.41, p=.016$ ).

Gender differences and age trends. None of the means-ends dimensions showed any gender effects, either as main effect or interaction; however, two Age $\times$ East versus West Berlin interactions did emerge for the means-ends dimensions.

The first interaction, for Means-ends: Teacher, appeared as an increasing linear component $(z=3.79, p<.001)$ with a $U$ shaped quadratic trend for the East Berlin children $(z=3.34$, $p<.001)$ but as a decreasing linear trend $(z=-3.28, p<.001)$ with a $U$-shaped quadratic component $(z=3.64, p<.01)$ for the West Berlin children; this interaction explains the mean differences in Grades 5 and 6, described above. The other Grade $\times$ East versus West Berlin interaction, Means-ends: Luck, appeared as a U-shaped quadratic trend for the East Berlin children $(z=3.32, p<.001)$ but as a decreasing linear trend $(z=$ $-7.62, p<.001$ ) for the West Berlin children. Regarding the remaining three means-ends constructs, Means-ends: Effort showed an increasing linear component $(z=2.95, p<.01)$ for both East and West Berlin; Means-ends: Ability evinced only a U-shaped quadratic component $(z=2.20, p<.05)$ for both samples; and Means-ends: Unknown showed a downwardbending quadratic trend for both East and West Berlin children $(z=-3.15, p<.01)$.

Strength of relationship to Academic Performance. As can be seen in Table 2, of the 25 correlations involving the meansends dimensions, none of the correlations approached the magnitudes evinced for the agency and control belief dimensions; in fact, only 5 reached a level significant different from zero (i.e., $p<.01)$. However, and more important, none of the pairs of correlations evinced a significant (i.e., $p<.01$ ) East versus West Berlin difference except the Means-ends: Effort dimension in Grade 3.

\section{Discussion}

In the present intracultural comparison of children's school performance-related beliefs and their relationship to Academic Performance, we observed marked context effects in the predicted direction. 
Table 2

Estimated Relationships Between Academic Performance and the CAMI Constructs by Grade Level and for All Students

\begin{tabular}{|c|c|c|c|c|c|c|c|c|c|c|c|c|c|}
\hline \multirow[b]{2}{*}{ CAMI construct } & \multirow[b]{2}{*}{ Type } & \multicolumn{6}{|c|}{ East Berlin (grade) } & \multicolumn{6}{|c|}{ West Berlin (grade) } \\
\hline & & 2 & 3 & 4 & 5 & 6 & Total & 2 & 3 & 4 & 5 & 6 & Total \\
\hline \multicolumn{14}{|l|}{ Agency beliefs } \\
\hline \multirow[t]{2}{*}{ EAL } & Dis & $.79^{* * * *}$ & $.74^{* * * *}$ & .72 & $.75^{* *}$ & $.88^{* * *}$ & $.77^{* * *}$ & $.61^{* * *}$ & $.60^{* * *}$ & .77 & $.67^{* *}$ & $.83^{* * *}$ & $.68^{* * *}$ \\
\hline & Raw & .74 & .69 & .62 & .64 & .83 & .70 & .47 & .58 & .66 & .54 & .76 & .59 \\
\hline \multirow[t]{2}{*}{ Effort } & Dis & $.81^{* * * *}$ & $.76^{* * *}$ & $.52^{* * *}$ & .61 & .80 & $.72^{* * *}$ & $.54^{* * * *}$ & $.58^{* * *}$ & $.73^{* * *}$ & .54 & .81 & $.63^{* * *}$ \\
\hline & Raw & .72 & .71 & .45 & .56 & .76 & .63 & .38 & .53 & .60 & .42 & .71 & .50 \\
\hline \multirow[t]{2}{*}{ Ability } & Dis & .69 & .65 & .75 & $.78^{*}$ & .86 & $.74^{* *}$ & .67 & .60 & .76 & $.71^{*}$ & .85 & $.70^{* *}$ \\
\hline & Raw & .61 & .58 & .59 & .61 & .80 & .63 & .45 & .52 & .59 & .52 & .73 & .55 \\
\hline \multirow[t]{2}{*}{ Luck } & Dis & $.83^{* * *}$ & .65 & .79 & $.72 * *$ & $.90^{* * *}$ & $.74^{* * * *}$ & $.63^{* * *}$ & .58 & .78 & $.60^{* *}$ & $.65^{* * *}$ & $.62^{* * *}$ \\
\hline & Raw & .73 & .58 & .58 & .58 & .76 & .64 & .42 & .52 & .62 & .47 & .58 & .54 \\
\hline \multirow[t]{2}{*}{ Teacher } & Dis & .54 & $.54^{*}$ & .32 & .38 & $.71^{* * * *}$ & $.47^{* *}$ & .40 & $.38^{*}$ & .36 & .32 & $.45^{* * * *}$ & $.36^{* *}$ \\
\hline & Raw & .42 & .51 & .23 & .35 & .54 & .35 & .30 & .30 & .29 & .23 & .40 & .29 \\
\hline \multicolumn{14}{|c|}{ Means-ends beliefs } \\
\hline \multirow[t]{2}{*}{ Effort } & Dis & .31 & $.51^{*}$ & .01 & .26 & .19 & .26 & .36 & $.28^{*}$ & .05 & .03 & .01 & .17 \\
\hline & Raw & .24 & .36 & .02 & .16 & .17 & .13 & .22 & .24 & .04 & -.04 & .05 & .09 \\
\hline \multirow[t]{2}{*}{ Ability } & Dis & .40 & .31 & .35 & .08 & .02 & .26 & .33 & .31 & .10 & .05 & .11 & .20 \\
\hline & Raw & .31 & .19 & .22 & .05 & .05 & .16 & .24 & .27 & .08 & .04 & .10 & .19 \\
\hline \multirow[t]{2}{*}{ Luck } & Dis & -.20 & -.26 & -.27 & -.15 & -.34 & -.24 & -.11 & -.09 & -.26 & -.27 & -.28 & -.17 \\
\hline & Raw & -.15 & -.29 & -.22 & -.17 & -.34 & -.19 & -.07 & -.08 & -.15 & -.18 & -.13 & -.03 \\
\hline \multirow[t]{2}{*}{ Teacher } & Dis & -.33 & -.13 & .00 & -.01 & -.20 & -.14 & -.21 & -.02 & -.18 & -.09 & -.30 & -.15 \\
\hline & Raw & -.22 & -.22 & -.02 & -.12 & -.09 & -.16 & -.15 & -.02 & -.10 & -.06 & -.13 & -.03 \\
\hline \multirow[t]{2}{*}{ Unknown causes } & Dis & .03 & -.18 & -.07 & -.08 & .04 & -.07 & -.02 & .04 & -.04 & -.13 & .01 & -.02 \\
\hline & Raw & -.01 & -.19 & -.06 & -.04 & -.10 & -.07 & -.01 & -.01 & .03 & .02 & .02 & -.02 \\
\hline \multirow[t]{2}{*}{ Control beliefs } & Dis & $.68^{* *}$ & $.66^{* *}$ & .48 & .49 & $.83^{* * *}$ & $.62^{* * *}$ & $.57^{* *}$ & $.46^{* *}$ & .51 & .49 & $.75^{* * * *}$ & $.52^{* * * *}$ \\
\hline & Raw & .54 & .47 & .34 & .34 & $.67^{* * *}$ & .46 & .37 & .34 & .42 & .41 & .57 & .41 \\
\hline$n$ & & 58 & 63 & 64 & 74 & 54 & 313 & 112 & 115 & 113 & 104 & 73 & 517 \\
\hline
\end{tabular}

Note. The effects of gender have been partialed from the grade estimates, and the effects of gender, linear grade, and quadratic grade have been partialed from the overall (total) estimates. Tests of significance were performed using an $r$-to- $z$ transformation and the pooled standard errors of the maximum likelihood estimates: two-tailed for the five types of Means-ends beliefs, one-tailed for the agency and control beliefs. All of the disattenuated correlations for the agency and control beliefs are significantly greater than zero $(p<.01)$, except for the ones denoted by italics. For the meansends dimensions, all disattenuated correlations are not greater than zero $(p>.01)$, except the ones denoted by italics. The significance from zero is based on the LISREL $T$ values associated with all estimated parameters (see Jöreskog \& Sörbom, 1989). Type $=$ type of statistic reported: dis $=$ maximum likelihood estimates of the disattenuated correlations; raw = raw data Pearson product-moment correlation.

${ }^{*} p \leq .05$. ${ }^{* *} p \leq .01 .{ }^{* * *} p \leq .001$, for East-West differences for the corresponding grade levels.

\section{Differences}

Beginning with the third grade, East Berlin children showed lower levels of agency and control beliefs than West Berlin children. In addition, the correlational nexus of agency and control beliefs with school performance was sizable and stronger in East Berlin than in West Berlin children. It was important that the two schools within East and West Berlin did not differ from each other in any of the target variables.

The mean differences between East and West Berlin children in agency and control beliefs applied to each of the agency components (ability, effort, luck, and teacher) and amounted to approximately $3 \%$ of the total variance. Furthermore, the difference emerged in the third through sixth grades, but did not appear in the younger and less school-experienced children (i.e., second graders), suggesting that the school system was a primary factor in shaping the differences observed. To evaluate the absolute levels of agency and control beliefs displayed by East and West Berlin children is, of course, difficult. No statistical norms are available, nor does a theory exist that would specify functional threshold levels for self-efficacy or agency beliefs in terms of absolute values.

The magnitude of the correlational nexus for agency and con- trol beliefs with school performance observed in Berlin children and especially in East Berlin children is remarkable for two reasons: its absolute size and its early age of onset. The overall raw correlation between the combined agency dimension (Agency: EAL) and academic performance in East Berlin was .70 (disattenuated .77), in West Berlin .59 (disattenuated .68). Correlations of the size observed in East Berlin children imply that children's conceptions of their own potential (in terms of selfattributed access to ability, effort, and luck) is close to isomorphic with their teacher-evaluated academic performance (i.e., the reliable variance shared between agency beliefs and school grades in East Berlin children was about 60\%). Furthermore, the differences in magnitudes of the correlations between East and West Berlin children were significant for agency beliefs concerning all four means and amounted to an average effect size of $12 \%$. Finally, this difference appeared already at the youngest age studied (Grade 2), reflecting the early onset of performance feedback in East Berlin.

When evaluating these correlations, both in East and West Berlin children, placing them into the context of research from the United States is useful. In the United States, correlations between agency beliefs and performance in the same age range 
assessed with a similar instrument as the one used here did not exceed the .30s (Skinner et al., 1990). Although this was not the focus of our research, this sizable difference between Berlin and American schools may deserve attention in its own right. For instance, the American elementary school system (or at least the schools studied) may emphasize (relatively speaking) selfdevelopment over precise performance feedback. We return to this issue later when discussing the possible sources and implications of the present data for the future development of East and West Berlin children.

\section{Similarities}

Means-ends or causality beliefs, the conceptions held by East and West Berlin children of how school performance in general comes about, were nearly identical, with one exception: Older East Berlin children assigned a more powerful role to teachers than their West Berlin peers. Similarities also applied to other facets of this research. For instance, as in earlier studies (Chapman et al., 1990), means-ends beliefs did not evince any substantial correlations with intellectual performance. The nexus between beliefs and performance was restricted to agency and control beliefs, a finding that is in line with the literature on self-efficacy and optimistic thinking (M. Baltes \& Baltes, 1986; Bandura, 1990; Schunk, 1989, 1991; Sternberg \& Kolligian, 1990; Taylor, 1989). Moreover, as predicted by the theoretical model (Skinner et al., 1988a) and past research, agency beliefs, with their specification of the relevant means, correlated more positively with school performance than did general control beliefs, which do not specify the relevant means. The predictive superiority of agency beliefs over control beliefs turned out to be complete: After agency beliefs were controlled for, no additional variance in academic performance was accounted for by control beliefs.

The observed similarities have two implications that are important for our interpretation. First, the general framework of our theoretical and empirical approach appears to be based on a solid foundation. For instance, because of the invariance of the measurement space, the differences obtained between East and West Berlin children are likely not due to a differential use of the instrument rating scales; that is, no evidence of a response set effect nor a restricted range of variance appeared in either of the samples. Second, the close-to-perfect similarity in meansends beliefs supports the basic assumption of this study. Specifically, despite different political systems between 1945 and 1990, East and West Berlin shared their cultural heritage; therefore, the observed differences in agency and control beliefs and their linkage to academic performance are not grounded in different worldviews about how school performance comes about.

\section{Sources of the Observed Differences Between East and West Berlin Children}

Which factors might be responsible for the observed differences between East and West Berlin children? One is tempted to identify the political makeup of the respective contexts, totalitarian-communism versus democratic capitalism, as the likely source. So far we have refrained from such a "distal-cause" ex- planatory orientation and, instead, have focused our hypotheses on more proximal causes associated with the school context. Such a school context-oriented approach does not deny the important role of more general political system factors. Schools are, in part, the outcome of political mandates. As psychologists, however, we focused on explanations that are part of the more proximal social and educational transactions between teachers and their children, acknowledging of course the possibility that these more proximal factors themselves are embedded in a larger macrostructural societal and political context.

Evaluation practices. Our primary explanatory hypothesis was that the East Berlin educational system had a strong focus on the development "of an adequate reality orientation" in children, a goal implemented by, among other means, public performance feedback from the first grade on. Praise and negative sanctions were announced in front of the class, and in case of low performance, children had to accept the unsolicited help from their peers imposed by their teachers. Thus, right from the beginning of school, pride and shame were directly linked to public respect granted by the teacher and the class-collective (Franz, 1987; Waterkamp, 1988).

That such publicly presented performance feedback and selfevaluations produce changes in self-conceptions can be delineated from several lines of research, social psychological as well as educational and child developmental. For instance, we know that open acceptance of judgments by an audience facilitates changes in personal belief systems (e.g., Axsom, Yates, \& Chaiken, 1987; Higgins \& Rholes, 1978) and that publicly announced beliefs readily lead to their private acceptance (Janis, 1968; Janis \& King, 1954). Furthermore, unsolicited help can lead children to lower their evaluations of their own competence (Graham \& Barker, 1990). A directly relevant experimental study in the school context was conducted by Franz (1982), an educational psychologist of the former East Germany. She varied whether self-evaluations were kept private or publicly announced and, as expected, obtained a greater increase in the degree of consensus between self-perceived competence and teacher feedback in the public than in the private condition.

Relevant findings also pertain to the role of educational contexts in shaping the level and development of self-efficacy (Sternberg \& Kolligian, 1990; Stipek, 1988). For instance, school entrance can reduce the generally high (often unrealistically high) level of self-efficacy or competence beliefs (Stipek, 1984, 1988). Optimistic self-evaluations typical for young children can be decreased by frequent public evaluations by the teacher as early as kindergarten (Stipek \& Daniels, 1988), and even preschool children can make realistic judgments about future performance if their attention is directed to past performance (Stipek, Roberts, \& Sandborn, 1984). Additionally, starting with second grade, children use processes of social comparison (Ruble, Boggiano, Feldman, \& Loebl, 1980; see also Ruble, 1983).

Teaching strategies. The contrast of unidimensional versus multidimensional teaching strategies (Rosenholtz \& Rosenholtz, 1981; Rosenholtz \& Simpson, 1984; Simpson, 1981) is also relevant for our interpretation of the East versus West Berlin differences. A multidimensional teaching format is geared toward teaching students on an individual basis, both with regard to kind of study materials and tasks and with regard to pace of studying. In contrast, a unidimensional educational for- 
mat emphasizes group-based strategies. By giving the same materials to all students at the same time, a unidimensional format facilitates a differentiated, comparative, and transparent grading system (Mac Iver, 1987, 1988; Rosenholtz \& Rosenholtz, 1981; Simpson, 1981) and thereby social comparison (see also Marshall \& Weinstein, 1986; Pepitone, 1972). Students taught in multidimensional versus unidimensional classrooms differ in evaluations of their potential. Multidimensionally taught students show higher levels of subjective potential and a weaker link between subjective potential and both teacher and peer evaluations than do unidimensionally taught students (Rosenholtz \& Rosenholtz, 1981; Simpson, 1981).

The East Berlin school context was reported to be more unidimensional than the West Berlin school context (Helwig, 1988; Waterkamp, 1990). Also, the teachers were to focus on the class as a whole and to limit children's attempts toward autonomy (Giessmann, 1990; Waterkamp, 1990). Teachers themselves were expected to adhere closely to the curriculum and regulations. Their compliance was supervised in learning conferences in front of colleagues, state officials, and the director of the school (Klier, 1990; see also Waterkamp, 1990). Such information supports our interpretation that the public evaluation practices within the context of a strictly unidimensional teaching strategy promoted more negative self-efficacy beliefs in East than in West Berlin, as well as stronger realism, when measured against the yardstick of teacher-based grading. Whether the various teaching practices interacted in an additive or multiplicative way, we do not know (for respective implications see Ames, 1992).

Achievement goals and subjective classroom perception. Differences between East and West Berlin classrooms, about which we have less information, might have also played a role. For example, East and West Berlin classrooms might have differed in achievement goals. From the literature on the effects of classroom structures on achievement goals (see Ames, 1992), we speculate that East Berlin may have focused more on performance goals than on mastery or learning goals, whereas the reverse might have been true for West Berlin (Ames \& Archer, 1988; Dweck, 1986; Dweck \& Leggett, 1988). Likewise, the school system in East Berlin might have reinforced ego involvement more than task involvement (Nicholls, 1984). A focus on ego involvement would have made East Berlin children even more vulnerable to using social comparison information for negative self-attributions (Jagacinski \& Nicholls, 1987). Finally, the subjective experience of classroom environments and the meaning children attribute to these experiences (Ames, 1992; Meece, Blumenfeld, \& Hoyle, 1988; Ryan \& Grolnick, 1986; Weinstein, 1989) might have varied with the different school environments in East and West Berlin. For example, our observation that East Berlin fifth and sixth graders ascribed a more important causal role in producing school outcomes to the help of the teacher than did their West Berlin peers does not necessarily imply an actual difference in teacher behavior; it may only reflect a differential perception of teacher behavior in older East and West Berlin children.

School-external sources. We mentioned that our preferred explanatory focus was on the proximal causes of the school context and not on the more general societal-political contexts in East and West Berlin. However, to show how the school context might have interacted with school-external forces, re- sulting in more pessimistic and "adequate" self-evaluations of children's potential in East than West Berlin, the following observations are offered. Survey research has shown (Sturzbecher, 1992) that East German parents as compared with West German parents wanted their children to be less autonomous, less self-reliant, less open-minded, and less critical-the child of their wishes was comparatively more obedient, tidy, polite, and responsible. Such socialization expectations are consistent with the outcome of lower agency and control beliefs and a stronger nexus for agency and control beliefs with performance in East Berlin. Among additional societal factors were the relative lack of emphasis on privacy in daily life in East Berlin and the degree of overlap among different life domains. Public announcement of performance was the norm in former East Germany (Bierwisch, 1990). Also, the daily life of East Berlin children was characterized by a high degree of overlap between school and social life. School and nonschool environments (e.g., social) were supposed to reinforce each other in pursuing the official goals of educating or reeducating children and adults to adopt the values of the communist authority (Waterkamp, 1990). Accordingly, most children of one classroom met each other again after school (this afternoon classroom was now named friendship), facilitating consistent and global evaluations (Giessmann, 1990). Social gatherings, apart from those in the class-collective (or friendship to which the children belonged throughout their school time), were discouraged (Waterkamp, 1990). We submit that school experiences are likely to have the kind of effectsthe powerful kind observed in this study-only if they are in concert with experiences outside of school.

In West Berlin, on the other hand, as in many other Western countries, there has been more emphasis on privacy and on separation of different sectors of life. Such pluralism offers more opportunity for the operation of self-protective illusions (Brandtstädter \& Greve, in press; J. Heckhausen \& Schulz, 1993; Sternberg \& Kolligian, 1990; Taylor, 1989) and for corrections of school-related feedback by school-external interaction and feedback systems. This separation of feedback systems in Western societies, practiced perhaps most intensively in the United States, may also be one of the reasons why the correlational nexus for agency and control beliefs with academic performance is so much lower in the American schools studied by Skinner et al. (1990). More cross-cultural research, however, is needed for examining this possibility.

\section{Consequences of the Observed Differences: Are East Berlin Children More at Risk?}

We mentioned the conceptual and empirical difficulty in evaluating the consequences of the reported East versus West Berlin differences. If one were to rely on Western research and its prevailing notions about subjective potential (such as selfefficacy or optimism and their consequences; Bandura, 1990, 1991; Flammer, 1990; Schunk, 1989, 1991; Sternberg \& Kolligian, 1990; Taylor, 1989), the observed differences can be interpreted as involving a risk factor for East Berlin children, particularly as they enter the world of unified Germany.

Low levels of self-efficacy produce motivational, affective, and cognitive deficits (Bandura, 1986, 1990, 1991; Schunk, 1989, 1991). For example, an individual with a low sense of 
efficacy gives up earlier in the face of setbacks, increasing the likelihood of future failure, which in turn reduces trust in one's efficacy (Bandura, 1986, 1990; Schunk, 1989, 1991). People with low self-efficacy beliefs have more fear of failure and solve tasks less analytically and pragmatically (Bandura, 1981, 1990; Pintrich \& De Groot, 1990; Wood \& Bandura, 1989). Moreover, they have reduced standards and aspirations when it comes to choosing career and other long-term goals (Betz \& Hackett, 1986). East Berlin children's lower levels of agency beliefs may therefore lead to negative consequences not only in school (e.g., giving up on tasks, fear of failure, and lack of problem-solving strategies) but also in achievement situations later on. We emphasize again, however, that we do not know which level of agency and control beliefs actually falls below a functional threshold such that the levels of belief can be characterized as posing a developmental risk.

In addition to the lower levels of agency and control beliefs, the comparatively higher positive relationship between these beliefs and grades in East Berlin children may also be a risk factor. Some convergence between self-related beliefs involving agency and control and performance is desirable, of course. However, school grades are only one outcome criterion of one's intellectual potential. Furthermore, the early onset of the high correlation for agency and control beliefs with performance means that East Berlin children's performance-related beliefs are fixed at a very early age. This early fixation might be a problem, particularly for those students who, for whatever reasons (lack of talent or motivational problems), show weak performances in the first years of schooling. They possibly form a negative concept of their own performance-related potential, and this as early as the second grade.

Whether such an interpretation of risk was true for children who spent their lives in the former East Germany is not clear, however. East Berlin children's beliefs and their exceedingly strong convergence with school grades may reflect the requirements of their political and educational context, which focused on a shared view in the class-collective and "adequate self-appraisal" rather than on individual optimism and self-protection (Franz, 1982, 1987). A society focusing on collectively shared views and on stabilizing the collective itself may therefore have favored a person who is high on realistic self-appraisal. Not surprisingly, then, students who conveyed to the teacher and the class-collective an adequate self-knowledge are praised and rewarded by being allowed to take on official positions in the classcollective (Waterkamp, 1988).

These considerations suggest contextual variations in the adaptation of performance-related beliefs and their connection to school performance. We need to acknowledge, therefore, that the question of what is ideal in terms of school performancerelated beliefs is a question of "gains and losses" (P. Baltes, 1987) and of the micro- and macroenvironments (Bronfenbrenner, 1976) in which people live. Our interpretation of the East Berlin findings as posing a risk factor is much influenced by Western conceptions of children's continuing quests for autonomy and self-actualization. Western research perspectives, stressing adaptability and plasticity in human development (Brim \& Kagan, 1980), suggest that children should keep a positive view of their potential as long as possible (Stipek, 1991; Taylor, 1989) and that their self-view should not be influenced by school grades too strongly nor too early in development. The cost of such individual plasticity, however, might be a lack of adequate self-knowledge, as well as a lack of shared views and stability in the collective (for an extensive review of concepts pertaining to individualism and collectivism see Berman, 1990).

Unfortunately, it is now too late to test the short- and longterm effects of East Berlin children's performance-related beliefs within the political and educational system of the former East Germany. We can only test them in the context of the changing political conditions of East Germany. Because East Berlin children are now exposed to the West Berlin school system, we predict that the eventual consequences will be similar to those shown in Western research settings. However, the question of how stable the observed differences in performance-related beliefs are over time remains an open one.

So far, performance-related beliefs assessed using the CAMI have been shown to be rather stable over time (see Skinner et al., 1988b). High stability is also observed in other areas of control beliefs (M. Baltes \& Baltes, 1986; Flammer, 1990). This research may, however, underestimate the plasticity of self-efficacy or agency beliefs. In Western countries, we have not experienced such a radical change in context as is currently occurring in East Berlin. In September 1991, the East Berlin schools adopted the West German school system. If development of children is flexible, we should observe diminishing differences of performance-related beliefs between East and West Berlin over the next years, with East Berlin data patterns approaching those of West Berlin. Such follow-up data would corroborate the findings of the present study and would also reveal specific characteristics of children who lose or gain most from the change to the West Berlin school system. Research is in progress to examine these questions.

\section{References}

Ames, C. (1992). Classrooms: Goals, structures, and student motivation. Journal of Educational Psychology, 84, 261-271.

Ames, C., \& Archer, J. (1988). Achievement goals in the classroom: Students' learning strategies and motivation processes. Journal of Educational Psychology, 80, 260-267.

Atkinson, J. W. (1957). Motivational determinants of risk-taking behavior. Psychological Review, 64, 359-372.

Axsom, D., Yates, S., \& Chaiken, S. (1987). Audience response as a heu* ristic cue in persuasion. Journal of Personality and Social Psychology, $53,30-40$.

Baltes, M. M., \& Baltes, P. B. (Eds.). (1986). The psychology of control and aging. Hillsdale, $\mathrm{NJ}$ : Erlbaum.

Baltes, P. B. (1987). Theoretical propositions of life-span developmental psychology: On the dynamics between growth and decline. Developmental Psychology, 23, 611-626.

Baltes, P. B., \& Nesselroade, J. R. (1973). The developmental analysis of individual differences on multiple measures. In J. R. Nesselroade \& H. W. Reese (Eds.), Life-span developmental psychology: Methodological issues (pp. 219-251). San Diego, CA: Academic Press.

Bandura, A. (1981). Self-referent thought: A developmental analysis of self-efficacy. In J. Flavell \& L. Ross (Eds.), Social cognitive development: Frontiers and possible futures (pp. 200-239). Cambridge, England: Cambridge University Press.

Bandura, A. (1986). The social foundations of thought and action: $A$ social cognitive theory. Englewood Cliffs, NJ: Prentice Hall. 
Bandura, A. (1990). Conclusion: Reflections on nonability determinants of competence. In R. J. Sternberg \& J. Kollegian, Jr. (Eds.), Competence considered (pp. 315-362). New Haven, CT: Yale University Press.

Bandura, A. (1991). Self-regulation of motivation through anticipatory and self-reactive mechanisms. Nebraska Symposium on Motivation. $38,69-163$.

Bentler, P. M. (1989). EQS structural equations program manual. Los Angeles, CA: BMDP Statistical Software.

Bentler, P. M., \& Bonett, D. G. (1980). Significance tests and goodness of fit in the analysis of covariance structures. Psychological Bulletin, $88,588-606$.

Berman, J. J. (Ed.). (1990). Cross-cultural perspectives: Nebraska Sympositum on Motivation, 1989. Lincoln: University of Nebraska.

Betz, N. E., \& Hackett, G. (1986). Applications of self-efficacy theory to understanding career choice behavior. Journal of Social and Clinical Psychology, 4, 279-289.

Bierwisch, M. (1990). Wissenschaft im realen Sozialismus [Science in a socialist society]. Kursbuch, 101, 112-123.

Brandtstädter, J., \& Greve, W. (in press). The aging self: Stabilizing and protective processes. Developmental Review.

Brim, O. G., \& Kagan, J. (1980). Constancy and change: A view of the issues. In O. G. Brim, Jr., \& J. Kagan (Eds.), Constancy and change in human development (pp. 1-25). Cambridge, MA: Harvard University Press.

Bronfenbrenner, U. (1976). The experimental ecology of education. Teachers College Record, 78, 157-204.

Chapman, M., Skinner, E. A., \& Baltes, P. B. (1990). Interpreting correlations between children's perceived control and cognitive performance: Control, agency, or means-ends beliefs? Developmental Psychology, 26, 246-253.

DDR: Schule im Aufbruch [East Germany: School awakening]. [Special issue]. (1990). Pädagogik, 3.

Dweck, C. S. (1986). Motivational processes affecting learning. American Psychologist, 41, 1040-1048.

Dweck, C. S., \& Leggett, E. L. (1988). A social-cognitive approach to motivation and personality. Psychological Review, 95, 256-273.

Falkenhagen, H. (1989). Selbstbewußtsein, Selbstregulation und Selbstreflexion [Self-awareness, self-regulation, and self-reflection]. Erziehungswissenschaftliche Forschung, 13, 83-90.

Finck, W. (1989). Zu einigen Selbstparametern bei Schülern mit unterschiedlichem Lernverhalten [On some self-related parameters in school children differing in learning behavior]. Erziehungswissenschaftliche Forschung, 13, 101-110.

Flammer, A. (1990). Erfahrung der eigenen Wirksamkeit. Einfuhrung in die Psychologie der Kontrollmeinung [Experiencing self-efficacy. Introduction to the psychology of control beliefs]. Berlin, Germany: Huber.

Franz, S. (1982). Entwicklung der Selbsteinschätzung bei Schülern [Development of self-evaluation in school children]. Berlin, Germany: Volk und Wissen.

Franz, S. (1987). Unsere Schüler zur Selbsteinschätzung befähigen [Teaching self-evaluation to our students]. Berlin, Germany: Volk und Wissen.

Franz, S. (1989). Anforderungsbezogene Selbsteinschätzung bei Abiturstufenschülern und Studenten [Task-related self-evaluation in high school and university students]. Erziehungswissenschaftliche Forschung, 13, 48-59.

Frey, K. S., \& Ruble, D. N. (1990). Strategies for comparative evaluation: Maintaining a sense of competence across the life span. In R. J. Sternberg \& J. Kolligian, Jr. (Eds.), Competence considered (pp. 167189). New Haven, CT: Yale University Press.

Giessmann, B. (1990). Die FDJ an den Schulen der DDR-Chancen und Grenzen der Funktionswahrnehmung [The "Free German
Youth" Organization in the schools of the GDR-Opportunities and limits in its social perception]. Zeitschrift für Sozialisationsforschung und Erziehungssoziologie (1. Beiheft), 91-104.

Graham, S., \& Barker, G. P. (1990). The down side of help: An attributional-developmental analysis of helping behavior as a low-ability cue. Journal of Educational Psychology, 82, 7-14.

Harter, S. (1982). The Perceived Competence Scale for Children. Child Development, 53, 87-97.

Heckhausen, H. (1977). Achievement motivation and its constructs: A cognitive model. Motivation and Emotion, 1, 283-329.

Heckhausen, J., \& Schulz, R. (1993). Optimisation by selection and compensation: Balancing primary and secondary control in life-span development. International Journal of Behavioral Development, 16, 287-303.

Helmke, A. (1992). Selbstvertrauen und schulische Leistungen [Selfconfidence and school performance]. Göttingen, Germany: Hogrefe.

Helwig, G. (1988). "Solides Wissen und klassenmäßige Erziehung." Zur Einfuihrung in das Bildungssystem der DDR ["Solid knowledge and class-conscious education." Introduction to the education system of the GDR]. In G. Helwig (Ed.), Schule in der DDR [Schooling in the GDR] (pp. 5-36). Köln, Germany: Wissenschaft und Politik.

Higgins, E. T., \& Rholes, W. S. (1978). "Saying is believing." Effects of message modification on memory and liking for the person described. Journal of Experimental Social Psychology, 13, 141-154.

Horn, W. (1972). Begabungstestsystem [Ability test system]. Göttingen, Germany: Hogrefe.

Jagacinski, C. M., \& Nicholls, J. G. (1987). Competence and affect in task involvement and ego involvement: The impact of social comparison information. Journal of Educational Psychology, 79, 107-114.

Janis, I. L. (1968). Attitude change via role playing. In R. Abelson, E. Aronson, W. McGuire, T. Newcomb, M. Rosenberg, \& P. Tennenbaum (Eds.), Theories of cognitive consistency: A sourcebook (pp. 810-818). Chicago, IL: Rand-McNally.

Janis, I. L., \& King, B. T. (1954). The influence of role playing on opinion change. Journal of Abnormal and Social Psychology, 49, 211-218.

Jöreskog, K. G., \& Sörbom, D. (1989). LISREL 7: A guide to the program and applications (2nd ed.). Chicago, IL: SPSS.

Klier, F. (1990). Lüg Vaterland, Erziehung in der DDR [Lie fatherland. Education in the GDR]. München, Germany: Kindler.

Krause, C. (1989). Zur Genese des Selbstbildes im Kindes- und Jugendalter-Ergebnisse und Probleme einer Längsschnittuntersuchung [The development of the self-image in childhood and adolescenceResults and problems of a longitudinal investigation]. Erziehungswissenschaftliche Forschung, 13, 7-30.

Little, T. D. (1993). Selection effects and factorial invariance in mean and covariance structures (MACS) analyses of cross-cultural data. Manuscript submitted for publication.

Little, T. D., Oettingen, G., Stetsenko, A., \& Baltes, P. B. (1993). A mean and covariance structures (MACS) assessment of the factor structure of the control, agency, and means-ends interview (CAMI) across seven cultures: Internal and cross-sample validation (ACCD Tech. Rep. No. 1). Berlin, Germany: Max Planck Institute for Human Development and Education.

Mac Iver, D. (1987). Classroom factors and student characteristics predicting students* use of achievement standards during self-assessment. Child Development, 58, 1258-1271.

Mac Iver, D. (1988). Classroom environments and the stratification of pupils' ability perceptions. Journal of Educational Psychology, 80 . 495-505.

Marsh, H. W., Balla, J. R., \& McDonald, R. P. (1988). Goodness-of-fit indexes in confirmatory factor analysis: The effect of sample size. Psychological Bulletin, 103, 391-410.

Marshall, H. H., \& Weinstein, R. S. (1986). Classroom context of stu- 
dent-perceived differential teacher treatment. Journal of Educational Psychology, 78, 441-453.

Meece, J. L., Blumenfeld, P. C., \& Hoyle, R. H. (1988). Students' goal orientations and cognitive engagement in classroom activities. Journal of Educational Psychology, 80, 514-523.

Nicholls, J. G. (1984). Achievement motivation: Conceptions of ability, subjective experience, task choice, and performance. Psychological Review, 91, 328-346.

Nicholls, J. G., \& Miller, A. T. (1985). Differentiation of the concept of luck and skill. Developmental Psychology, 21, 76-82.

Oettingen, G. (in press). Explanatory style in the context of culture. In G. Buchanan \& M. E. P. Seligman (Eds.), Explanatory style. Hillsdale, NJ: Erlbaum.

Oettingen, G., \& Seligman, M. E. P. (1990). Pessimism and behavioural signs of depression in East versus West Berlin. European Journal of Social Psychology, 20, 207-220.

Pekrun, R. (1987). Die Entwicklung leistungsbezogener Identität bei Schülern [The development of performance-related identity in school children]. In H.-P. Frey \& K. Haußer (Eds.), Identität [Identity] (pp. 43-57). Stuttgart, Germany: Enke.

Pepitone, E. (1972). Comparison behavior in elementary school children. American Educational Research Journal, 9, 43-63.

Pintrich, P. R., \& De Groot, E. V. (1990). Motivational and self-regulated learning components of classroom academic performance. Journal of Educational Psychology, 82, 33-40.

Rholes, W. S., Newman, L. S., \& Ruble, D. N. (1990). Understanding self and other: Developmental and motivational aspects of perceiving persons in terms of invariant dispositions. In E. T. Higgins \& R. M. Sorrentino (Eds.), Handbook of motivation and cognition: Foundations of social behavior (Vol. 2, pp. 369-407). New York: Guilford Press.

Rosenholtz, S. J., \& Rosenholtz, S. H. (1981). Classroom organization and the perception of ability. Sociology of Education, 54, 132-140.

Rosenholtz, S. J., \& Simpson, C. (1984). The formation of ability conceptions: Developmental trend or social construction? Review of Educational Research, 54, 31-63.

Ruble, D. (1983). The development of social-comparison processes and their role in achievement-related self-socialization. In E. T. Higgins, D. Ruble, \& W. W, Hartup (Eds.), Social cognition and social development (pp. 134-157). New York: Cambridge University Press.

Ruble, D.. Boggiano, A., Feldman, N., \& Loebl, J. (1980). Developmental analysis of the role of social comparison in self-evaluation. Developmental Psychology, 16, 105-115.

Ryan, R. M., \& Grolnick, W. S. (1986). Origins and pawns in the classroom: Self-report and projective assessments of individual differences in children's perceptions. Journal of Personality and Social Psychology, 50, 550-558.

Schnabel, G. (1977). Die Selbst- und Fremdeinschätzung: Wesentliche Mittel der Charakterentwicklung [Self- and other evaluations: Critical means for character development]. Pädagogische Lesung [Educational Readings]. Berlin, Germany: Deutsches Institut für internationale pädagogische Forschung.

Schunk, D. H. (1989). Self-efficacy and cognitive skill learning. In C. Ames \& R. Ames (Eds.), Research on motivation in education (Vol. 3, pp. 13-44). San Diego, CA: Academic Press.

Schunk, D. H. (1991). Self-efficacy and academic motivation. Educational Psychologist, 26, 207-231

Seligman, M. E. P., \& Elder, G. H., Jr. (1986). Learned helplessness and life-span development. In A. B. Sorensen, F. E. Weinert, \& L. R. Sherrod (Eds.), Human development and the life course: Multidisciplinary perspectives (pp. 377-428). Hillsdale, NJ: Erlbaum.

Simpson, C. (1981). Classroom structure and the organization of ability. Sociology of Education, 54, 120-132.

Skinner, E. A., Chapman, M., \& Baltes, P. B. (1988a). The control, agency, and means-ends beliefs interview. Materialien aus der Bildungsforschung, 31. Berlin, Germany: Max Planck Institute for Human Development and Education.

Skinner, E. A., Chapman, M., \& Baltes, P. B. (1988b). Control, meansends, and agency beliefs: A new conceptualization and its measurement during childhood. Journal of Personality and Social Psychology, 54, 117-133.

Skinner, E. A., Chapman, M., \& Baltes, P. B. (1988c). Children's beliefs about control, means-ends, and agency: Developmental differences during middle childhood. International Journal of Behavioral Development, 11, 369-388.

Skinner, E. A., Wellborn, J. G., \& Connell, J. P. (1990). What it takes to do well in school and whether I've got it: A process model of perceived control and children's engagement and achievement in school. Journal of Educational Psychology, 82, 22-32.

Sternberg, R. J., \& Kolligian, J., Jr. (Eds.). (1990). Competence considered. New Haven, CT: Yale University Press.

Stipek, D. J. (1984). The development of achievement motivation. In R. Ames \& C. Ames (Eds.), Research on motivation in education student motivation (Vol, 1, pp. 145-174). San Diego, CA: Academic Press.

Stipek, D. J. (1988). Motivation tó learn. From theory to practice. Englewood Cliffs, NJ: Prentice Hall.

Stipek, D. J. (1991). Characterizing early childhood education programs. New Directions for Child Development, 53, 47-55.

Stipek, D. J., \& Daniels, D. (1988). Declining perceptions of competence: A consequence of changes in the child or the educational environment? Journal of Educational Psychology, 80, 352-356.

Stipek, D. J., Roberts, T. A., \& Sanborn, M. E. (1984). Preschool-age children's performance expectations for themselves and another child as a function of the incentive value of success and the salience of past performance. Child Development, 55, 1983-1989.

Sturzbecher, D. (1992). Vergleichende Analyse elterlicher Erziehungsziele in der ehemaligen DDR und der alten Bundesrepublik [Comparative analysis of socialization values in former East Germany and West Germany]. Potsdam, Germany: University of Potsdam Institute for Family- and Childhood Research.

Tautz, D. (1978). Erfahrungen bei der Befähigung der Schüler zur realen Selbsteinschätzung [Experiences with teaching school children to realistically self-evaluate]. Pädagogische Lesung [Educational readings]. Berlin, Germany: Deutsches Institut für internationale pädagogische Forschung.

Taylor, S. E. (1989). Positive illusions. New York: Basic Books.

Tucker, L. R., \& Lewis, C. (1973). A reliability coefficient for maximum likelihood factor analysis. Psychometrika, 38, 1-10.

Waterkamp, D. (1987). Handbuch zum Bildungswesen der DDR [Handbook of the educational system of the GDR]. Berlin, Germany: Berlin Verlag.

Waterkamp, D. (1988). “Achtung Sammeln.” Disziplin in der Schule der DDR ["Attention: Assemble." Discipline in the school of the GDR]. In G. Helwig (Ed.), Schule in der DDR [School in the GDR] (pp. 37-64). Köln, Germany: Wissenschaft und Politik.

Waterkamp, D. (1990). Erziehung in der Schule [Education in the school]. In Bundesministerium für innerdeutsche Beziehungen (Ed.), Vergleich von Bildung und Erziehung in der Bundesrepublik Deutschland und in der Deutschen Demokratischen Republik [Comparison of education and upbringing in the Federal Republic of Germany and the German Democratic Republic] (pp. 261-277). Köln, Germany: Wissenschaft und Politik.

Wechsler, D. (1974). Wechsler Intelligence Scale for Children-Revised. New York: Psychological Corporation.

Weck, H. (1981). Bewertung und Zensierung [Evaluation and grading]. Berlin, Germany: Volk und Wissen.

Weinstein, R. S. (1989). Perceptions of classroom processes and student motivation: Children's views of self-fulfilling prophecies. In C. Ames 
\& R. Ames (Eds.), Research on motivation in education (Vol. 3, pp. 187-221). San Diego, CA: Academic Press.

Weisz, J. R. (1983). Can I control it? The pursuit of veridical answers across the life span. In P. B. Baltes \& O. G. Brim, Jr. (Eds.), Lifespan development and behavior (Vol. 5, pp. 233-300). San Diego, CA: Academic Press.

Weisz, J. R., \& Stipek, D. J. (1982). Competence, contingency, and the development of perceived control. Human Development, 25, 250281.

Widaman, K. F., \& Kishton, J. (1992). Alternative bases for parcelling items for confirmatory analyses: The item-versus-parcel contro- versy-revisited. Unpublished manuscript, University of California, Riverside.

Wiese, H. (1989). Zur Selbsteinschätzung bei Schülern 5. und 6. Klassen bezüglich ihrer Lernmotivation [On self-evaluative judgments of fifth and sixth graders with respect to their learning motivation]. Erziehungswissenschafiliche Forschung, 13, 117-123.

Witzlack, G. (1986). Verhallensbewertung und Schülerbeurteilung [Evaluating behavior and judging students]. Berlin, Germany: Volk und Wissen.

Wood, R. E., \& Bandura, A. (1989). Impact of conceptions of ability on self-regulatory mechanisms and complex decision-making. Journal of Personality and Social Psychology, 56, 407-415.

\section{Appendix}

\section{Details of the Mean and Covariance Structures (MACS) Modeling}

\section{Standardization of School Grades}

In the analyses reported, we standardized school grades within school class to remove variance due to mean differences between school classes. However, in a separate analysis, we compared East versus West differences in mean levels of school grades. To do so, we adjusted the scales for the grades by expanding the 5-point scale (1-5, where 1 was the higher and 5 the lower grade) used in East Berlin to the 6-point scale (0 to 5) used in West Berlin. The adjustment formula was $N G=[(G-1) /$ 4] $\times 5$, where $N G$ is the new grade and $G$ is the original grade. This adjustment lowered the mean levels to a comparable level of that for the West Berlin sample but artificially increased the variance. Therefore, the variances of the grade variables were held constant at the levels evinced in the original metric while standardizing the grades to the mean of the adjusted metric: $G=(G-M G)+M N G$, where $M G$ is the mean of the grades in the original metric and $M N G$ is the mean of the grades in the adjusted metric.

No mean differences in academic performance emerged between the East and West Berlin samples except a marginal trend in Grade 4, where East Berlin children tended to score higher than West Berlin children $(z$ $=1.92, p<.10$ ). Although this one trend emerged, the standardized results presented throughout the article were substantively identical to the unstandardized, but equated version (i.e., the above formula) of the indicators of academic performance. Representing either standardized or unstandardized grades in their respective models, the distributional qualities of the grades at each grade level were highly similar between the two samples; that is, all tests of nonnormality and inequality of variance were nonsignificant.

\section{Aggregation of Items}

For each of the four agency and five means-ends dimensions, we aggregated the six available items into three indicators. We used random assignment with a constraint in the aggregation process for these dimensions. The constraint was that each indicator would have one positively worded item and one negatively worded item from the respective subdomain. We imposed this constraint to ensure the heterogeneity of the factors and the balance of information represented by each indicator (Widaman \& Kishton, 1992). For the control dimension, only four positively worded items are assessed (see Little et al., 1993). Thus, the first two indicators for the control factor were the two positively worded items with the highest item-scale correlations, and the third indicator was the average of the remaining two items.

\author{
Model Specification
}

As mentioned, in addition to the basic constructs of the CAMI (i.e., 30 indicators for 10 factors in the 10 -factor model and 24 indicators for 8 factors in the 8-factor representation) and Academic Performance (represented by 2 indicators: the grades for verbal and math performance, respectively), we included three additional single-indicator variables in the models to estimate and thus control for (i.e., partial) their effects: linear grade, quadratic grade, and gender.

Because we performed the analyses on moment matrices among all indicators, we specified a Mean Level factor such that all indicators loaded on this factor, thus estimating the intercept or mean levels of each indicator. In addition, we imposed metric invariance of the factor loadings to ensure equality of measurement of all factors in each group in the analyses. We decomposed the variance and covariance information for each of the CAMI factors into variance and correlation information by estimating a second-order factor for each first-order factor. We estimated the variance of each latent factor as a directed path from the respective second-order factor to the respective first-order factor and fixed the first-order factor variance to zero. We fixed the estimate of variance (i.e., the directed path between the second- and first-order factors) at 1.0 in the first group to establish the scale of measurement. Because of the metric invariance constraint, we allowed this variance information to vary freely in each subsequent group. We fixed the variances of each second-order factor at 1.0 in each group to identify each factor and the overall model; furthermore, because we fixed all secondorder factor variances at 1.0, we could estimate the relations among the second-order factors as correlations. Also because of the metric invariance constraint, we could estimate the mean levels of the factors by fixing the latent mean estimate of the second-order CAMI factors in the first group and allowing the latent mean estimate to vary freely in each remaining group. Thus, we estimated the mean levels as mean differences relative to the first group, the variances as variance differences relative to the first group, and the covariances as correlations among the second-order factors (see Little, 1993, and Little et al., 1993, for details of this type of modeling procedure).

\section{Fit Statistics and Tests of Significance}

We assessed level of fit for each model using the nonnormed fit index (NNFI) of relative fit (also called rho, see Bentler \& Bonett, 1980; Tucker \& Lewis, 1973) and the incremental fit index (IFI; Marsh, Balla, \& McDonald, 1988). Following the convention of Bentler and Bonett, we used values greater than .90 as our criterion for acceptible fit. We specified 
two types of null model for these fit indices: a traditional null model (TNM), specifying only unique variances for the indicators (see Bentler \& Bonett, 1980) and a conservative null model (CNM), specifying both a mean level and a unique variance for each indicator; also, in the CNM, we constrained the mean level estimates for the indicators of the CAMI factors and academic performance to be equal in each group because (a) they were measured with similar metrics and (b) the null model assumes that the means of the indicators are indiscriminate with regard to any common factors (see Little, 1993; Little et al., 1993).

We evaluated all tests of significance as $z$ differences (i.e., as large sample $t$ tests of the difference between two estimates divided by the pooled maximum likelihood estimates of the standard error for each term). We calculated the differences between covariances by estimating the covariations in correlational metric, performing a Fisher's $r$-to- $z$ transformation of each estimate, and calculating the difference. We evaluated the tests of significance as one-tailed tests for our a priori hypotheses (e.g., the agency and control beliefs) and as two-tailed tests for the remaining comparisons (c.g., the means-ends beliefs and gender effects); furthermore, because of the large number of remaining comparisons, we adopted an alpha level of .01 to minimize Type I error.

\section{Fit Statistics for the Two-Group MACS Models}

For the model in which each of the agency dimensions of effort, ability, and luck were estimated separately, the TNM yielded a $\chi^{2}(1260, N$ $=830)=94001.35$ and the CNM yielded a $\chi^{2}(1250, N=830)=$ 33939.07. The level of fit of the metric equivalent measurement model was very acceptable: $\chi^{2}(993, N=830)=1907.97, \mathrm{NNFI}=.987$ and IFI $=.990$ with the $\mathrm{TNM}$ and $\mathrm{NNFI}=.965$ and $\mathrm{IFI}=.972$ with the $\mathrm{CNM}$. For the model in which each of the agency dimensions of effort, ability, and luck were estimated as a combined agency factor, the TNM yielded a $\chi^{2}(870, N=830)=76153.54$ and the CNM yielded a $\chi^{2}(860, N=$ $830)=20660.77$. The model fit was acceptable: $\chi^{2}(669, N=830)=$ $1496.61, \mathrm{NNFI}=.986$, and IFI $=.990$ with the $\mathrm{TNM}$ and NNFI $=.946$ and IFI $=.959$ for the CNM. When we estimated each of these models individually for each sample, the model fits were as high as the multiple group model and both samples evinced approximately equal levels of fit. For example, for the 10-factor model, NNFI $=.988$ and IFI $=.991$ for the East Berlin sample and NNFI $=.990$ and IFI $=.992$ for the West Berlin sample (using the TNM; see Little et al., 1993, for more details).
Fit Statistics for the 10-Group MACS Models

Both forms of the 10-group models also provided acceptable levels of fit. For the model in which each of the agency dimensions (i.e., effort, ability, and luck) were estimated separately, the TNM yielded a $\chi^{2}(5610$, $N=830)=97673.73$ and the CNM yielded a $\chi^{2}(5580, N=830)=$ 37614.70. The model fit was acceptable: $\chi^{2}(4677, N=830) 7112.48$, NNFI $=.968$ and IFI $=.974$ with the TNM and NNFI $=.909$ and IFI $=.926$ with the CNM. For the model in which each of the agency dimensions (i.e., effort, ability, and luck) were estimated as a combined factor, the TNM yielded a $\chi^{2}(3780, N=830)=76411.67$ and the CNM yielded a $\chi^{2}(3750, N=830)=25425.57$. The model fit was acceptable, $\chi^{2}(3141, N=830)=4852.00, \mathrm{NNFI}=.972$ and $\mathrm{IFI}=.977$ with the TNM and NNFI $=.906$ and IFI $=.923$ with the CNM (see Little et al., 1993, for more details).

\section{Evaluation of Gender Differences and Developmental Trends}

We used the two-group MACS model to evaluate gender differences and developmental trends in level of beliefs. Recall that this model contained estimates of gender effects as well as the linear and quadratic effects of grade. Furthermore, to test for interactions between East versus West Berlin on these variables, we placed a between-groups equality constraint on the respective estimates. This multivariate test of interaction effects was significant $\chi^{2}(20, N=830)=33.85, p=.03$. Our inspection of the modification indices revealed that relaxing the equality constraints for the linear and quadratic effects on Means-ends: Luck and Means-ends: Teacher were warranted. The resulting multivariate test, estimating the two means-ends interactions with grade level, was nonsignificant, $\chi^{2}(18, N=830)=15.15, p=.65$. Thus, the analyses showed no Gender $\times$ East versus West Berlin interactions for any of the CAMI constructs and only two Age $\times$ East versus West Berlin interactions (i.e., Means-ends: Luck and Means-ends: Teacher).

Received February 1, 1993

Revision received October 1, 1993 Accepted October 7, 1993 